\title{
Diseño de mezclas de hormigón reciclado mediante el método Volumen de Mortero Equivalente (EMV): validación bajo el contexto español y su adaptación al método de diseño de Bolomey
}

\section{Equivalent Mortar Volume (EMV) method for proportioning recycled aggregate concrete: validation under the Spanish context and its adaptation to Bolomey methodology for concrete proportioning}

\author{
C. Jiménez ${ }^{(*)}$, D. Aponte(*), E. Vázquez(*), M. Barra(*), S. Valls(*) \\ Recepción / Received: 9-IV-12 \\ Aceptación / Accepted: 20-VII-12 \\ Publicado online / Online publishing: 8-X-12
}

\section{RESUMEN}

El nuevo método para el diseño de hormigón con árido reciclado (HAR) es usado para comprobar su posibilidad de uso bajo el contexto español. Primeramente, se realiza una extensa campaña experimental, para analizar las posibilidades de su aplicación, usando dos áridos reciclados de hormigón (ARH) españoles. En la segunda etapa se elabora una adaptación del método a la metodología propuesta por Bolomey (1), con $20 \%$ de reemplazo en peso de árido grueso natural (AN) por ARH, para así cumplir con las recomendaciones estipuladas en la Instrucción de Hormigón Estructural (EHE 2008). Para determinar y analizar las propiedades del hormigón, se llevaron a cabo ensayos de asentamiento, contenido de aire, densidades, módulo elástico y resistencias a compresión. Finalmente, se concluye que el uso del nuevo método es viable, y que su adaptación produce hormigones con similares o mejores características que los elaborados para hormigón con árido convencional (HAC) y HAR convencionales.

Palabras clave: hormigón reciclado; árido reciclado; proporción de mezcla; propiedades mecánicas; cemento Pórtland.

\begin{abstract}
A new method for proportioning recycled aggregates concrete $(R A C)$ is used to check its feasibility under the Spanish context. First, an extensive experimental campaign has been done, with the purpose of check and analyze the applicability of the EMV method with two Spanish recycled concrete aggregates (RCA). The aim of the second part of the investigation, was to elaborate an adaptation of the EMV method to Bolomey methodology (1), using a 20\% weight replacement of coarse natural aggregates (NA) for RCA, and so, with this, comply with the Spanish Instruction for Structural Concrete (EHE 2008). Slump, air content, fresh and hardened densities, compressive strength and modulus of elasticity were determined and analyzed, in order to check the concrete properties. Finally, it was observed that, the EMV method is viable, and its adaptation, results in concrete mixes with similar or better properties than the natural aggregate concrete and RAC conventionally prepared.
\end{abstract}

Keywords: recycled concrete; recycled aggregate; mix proportioning; mechanical properties; Portland cement.

(*) Universidad Politécnica de Cataluña (Barcelona, España). 


\section{INTRODUCCIÓN}

Durante estos últimos años, la construcción sostenible se ha desarrollado de manera importante, considerando una gran cantidad de temas, y volviéndose de vital importancia gracias a la concienciación de la población acerca de los temas medio-ambientales. Uno de estos temas se relaciona con la reutilización y reciclaje de materiales provenientes de la construcción y demolición.

En el contexto europeo, el reciclaje de materiales de construcción y demolición, entre los años 1996 y 2006, en Holanda, Alemania y Dinamarca, ha sobrepasado el $80 \%$, mientras que en España, no ha pasado del 20\% (2). Sin embargo, estadísticas recientes en Cataluña, España, muestran que un $57,6 \%$ de los residuos de construcción han sido llevados a una planta de valorización (recuperación o reciclado), y el resto llevado a un vertedero controlado (3); esto supera con creces el $20 \%$ anteriormente mencionado. Ejemplos como éstos nos muestran las grandes diferencias existentes en lo que se refiere al uso de recursos.

El hormigón es un material de conocimiento extendido, y el más importante en el sector de la construcción (4, $5)$; sin embargo, su reciclaje sólo es común en países desarrollados, llegando a importantes niveles de utilización dependiendo de las políticas y reglamentos internos de cada país. Aun cuando el hormigón es un material medioambientalmente amigable (4), los volúmenes de producción del mismo y su posterior disposición en vertederos, cuando el material pasa a ser un residuo, generan un gran problema en países urbanizados donde el espacio para tales prácticas es reducido, y también, debido a los áridos naturales que necesita para su confección (6); es por esto que el reciclaje de hormigón para la producción de áridos reciclados (AR) representaría una importante solución.

Hoy en día, el diseño de mezclas de HAR se hace utilizando métodos convencionales de dosificación, tomando en cuenta las diferencias entre las características físicas del AR y el árido natural, como la densidad, porosidad, y absorción de agua, en donde esta última presenta las mayores discrepancias (7). Un punto importante a destacar, es que estas dosificaciones se basan en el uso de mayores contenidos de cemento para alcanzar propiedades similares a las de un HAC (7); esto significa que, aun cuando el HAR ayuda a disminuir el uso de recursos naturales, de vertederos, puede reducir las emisiones de $\mathrm{CO}_{2}$ causadas por el transporte de áridos, entre otras; podría necesitar más energía, causar más emisiones de $\mathrm{CO}_{2}$, y elevar el coste por unidad de hormigón debido al uso de mayores cantidades de cemento. Un documento recientemente publicado por la Agencia de Protección Ambiental de Estados Unidos (EPA) (8) muestra la importancia, en términos de emisiones de $\mathrm{CO}_{2}$, que la producción de cemento significa.

\section{INTRODUCTION}

Sustainable construction has been in develop through these last years, covering a wide range of topics and becoming of high importance because of the raise on the public awareness about environmental issues. One of these topics is related to the reuse and recycling of construction and demolition materials.

Among the European context, recycling of construction and demolition materials in Netherlands, Denmark and Germany for example, since year 1996 until 2006, has been over $80 \%$ while in Spain has not passed the $20 \%$ (2). Nevertheless, recent statistics from the year 2010 in Catalonia, Spain, exhibit that a $57.6 \%$ of the construction wastes were taken to a valorisation plant (recovery or recycling), and the rest was taken to a controlled dump (3); thus, over passing by far the $20 \%$ figure for whole Spain. These examples show us the existing differences in what using available resources means.

Concrete is a wide known material and the most important in the construction field $(4,5)$, however recycling it is not a common practice but in developed countries, reaching high levels of utilization depending on their internal policies and regulations. Although concrete is a green material (4), its production volumes represent a big problem, because of its disposal, when is treated as a waste, which is a main concern in urbanized countries where there is no more space for such purposes, and also because of the requirements on natural aggregates that it represents (6), so recycling it to produce new aggregate may represent an important solution.

In present, design mixes for RAC uses conventional methods on their design, taking into account the physical characteristics changes that natural aggregates and RCA have, like density, porosity and water absorption, where this last one presents the biggest difference when compared with natural aggregates (7). A significant point among them is that they rely on the use of more cement in order to achieve similar properties for the desired concrete (7); this means that, even though RAC helps to avoid depletion of natural resources, diminishes the use of dumps, can reduce the $\mathrm{CO}_{2}$ emissions caused by aggregates transportation, among others; it can take more energy, more $\mathrm{CO}_{2}$ emissions and raises the cost per unit of concrete because of the use of more cement. A recent document submitted by U.S. Environmental Protection Agency (EPA) (8) shows the significance that cement production has over $\mathrm{CO}_{2}$ emissions among several industrial processes in United States of America. Cement 
La producción de cemento alcanza el segundo lugar, después de la producción de acero y coque metalúrgico (41 $\mathrm{Tg})$, con $29 \mathrm{Tg}$, sobrepasando ampliamente los $11,8 \mathrm{Tg}$ de la tercera actividad (producción de amoníaco y consumo de urea). Maier y Durham (9) indican que el cemento Portland es el que mayor cantidad de gases invernadero produce, de entre todos los componentes del hormigón.

Dicho esto, la reducción de la cantidad de cemento necesaria para elaborar un hormigón, debería convertirse en una medida efectiva a la hora de reducir el consumo de energía y las emisiones de $\mathrm{CO}_{2}$ que la confección de hormigones conlleva. Por tanto, el método estudiado, nombrado Volumen de Mortero Equivalente (EMV por sus siglas en inglés) por sus autores, debería convertirse en un logro de gran importancia, ya que está basado en que el ARH es un material de dos fases (mortero y $\mathrm{AN}$ ), y para obtener propiedades similares a las de un HAC, estas deben ser tomadas en consideración. Esto se logra restando el mortero antiguo (contenido en el ARH) del nuevo, con el propósito de lograr una mezcla de HAR de igual volumen de mortero que un HAC, y así, reducir la necesidad de cemento.

\section{MATERIALES Y MÉTODOS}

\subsection{Estudio experimental}

Esta investigación ha sido dividida en dos partes. Primero, una verificación del nuevo método ha sido llevada a cabo para comprobar si era posible trabajar con los áridos elegidos y las condiciones seleccionadas. La segunda parte constó en hacer una adaptación del nuevo método a la metodología propuesta por Bolomey, y comprobar si era posible extrapolar la experiencia de los hormigones hechos en base al método ACI a otros métodos de diseño de mezclas. La metodología de Bolomey fue elegida por el hecho de representar una usada comúnmente.

La parte experimental de este estudio, incluye la determinación y el análisis de las características de los componentes usados en la elaboración de las mezclas, la fabricación de probetas de hormigón de diferentes características, para poder compararlas con el nuevo método, y el ensayo de las probetas, con el propósito de obtener sus propiedades mecánicas y físicas.

\subsection{Materiales}

El cemento utilizado es CEM I 42,5 R, de la compañía CEMEX S.A.B. Sus características cumplen con las especificaciones prescritas en la normativa UNE-EN 197-1 (10). Los áridos naturales utilizados fueron dos arenas calcáreas (I y II) y un árido grueso calizo, todos procedentes del mismo proveedor. Los ARH fueron obtenidos de dos fuentes; el primero, denominado $A$, se obtuvo de la trituración de production reaches the second place, after Steel and Metallurgical Coke production (41 Tg), with an amount of $29 \mathrm{Tg}$, exceeding by far the $11.8 \mathrm{Tg}$ of the third activity (Ammonia Production \& Urea Consumption). Maier and Durham (9) stated that Portland cement is the largest contributor to green house gases of all the raw materials used in concrete.

With this said, any success on reducing the necessary amounts of cement in a concrete mix would become an effective measure when trying to reduce energy consumption and $\mathrm{CO} 2$ emissions. Therefore, the studied method, named Equivalent Mortar Volume by its authors, should become in a major change among this issue, because is based on the fact that RCA is a two phase material (mortar and NA), and in order to obtain similar properties to a NAC, they must be taken into account. This is accomplished by basically resting the old mortar volume from the new needed one, which purpose is to achieve a RAC mix with an equal volume of mortar of a NAC; thus reducing some of the concrete components requirements, such as the cement.

\section{MATERIALS AND METHODS}

\subsection{Experimental study}

This investigation is divided in two major parts. In the first part, a verification of the new method was realized in order to check if it was feasible to work with the chosen aggregates and the selected characteristics. The second part consisted on taking the basis of the new method, trying to adapt them to Bolomey methodology, in order to check if it is possible to extrapolate the experience with ACI methodology into other kinds of concrete designs. Bolomey methodology was selected because it represents a commonly used method for concrete design.

The experimental part of this study includes the analysis and determination of the components characteristics for the elaboration of concrete, the fabrication of different concrete specimens, with different characteristics, in order to verify and compare them with the new mix design, and the testing of the concrete specimens in order to obtain their mechanical and physical characteristics.

\subsection{Materials}

The chosen cement was CEM I 42,5 $R$ provided by CEMEX S.A.B. company. Its characteristics comply with the specifications prescribed in UNE-EN 197-1 (10). Two types of calcareous sand, and one limestone, all of them obtained from the same supplier, were used as the fines and coarse natural aggregates. The RCA were obtained from two sources; an aggregate named recycled type $A(A)$ was 
probetas cilíndricas de hormigón, mediante un triturador de mandíbulas dispuesto en el laboratorio en donde se llevó a cabo la investigación; el segundo, denominado B, se obtuvo de una compañía de AR de Cataluña, España. En la primera parte de la investigación se utilizaron ambos AR y la arena I. En la segunda parte se utilizó el reciclado A y la arena II. El AN seleccionado fue utilizado en toda la investigación. Las características físicas de los áridos utilizados en la investigación se muestran en la Tabla 1. Un aditivo superplastificante (SP) (Glenium Sky 604) y un aditivo inclusor de aire (IA) (Micro Air 100), ambos de la empresa BASF, fueron utilizados en la investigación. obtained from crushing old cylindrical concrete specimens, with a jaw crusher, at the laboratory facilities, where the investigation took place, and recycled type $B(B)$ which was acquired from a recycling aggregates company, from Catalonia, Spain. Sand type $A$ and recycled aggregates type $A$ and $B$, were used in the first part of the investigation. The second part of the investigation only used sand type $B$ and recycled aggregates type $A$. The selected NA was used in the whole process. The aggregates main physical characteristics are shown in Table 1. A superplasticizer (SP) (Glenium Sky 604) and an air entrainer (AE) (Micro Air 100), both from BASF Company, were the chosen additives.

Tabla 1 / Table 1

Caracterización física de los áridos.

Physical characterization of aggregates.

\begin{tabular}{|c|c|c|c|c|c|c|}
\hline Árido / Aggregate & $\begin{array}{c}\text { Absorción / } \\
\text { Absorption (\%) }\end{array}$ & $\begin{array}{l}\text { Densidad seca } \\
\text { / OD specific } \\
\text { gravity }\left(\mathrm{kg} / \mathrm{m}^{3}\right)\end{array}$ & $\begin{array}{c}\text { Densidad SSS } \\
\text { / SSD Density } \\
\left.\text { (kg/m } / \mathrm{m}^{3}\right)\end{array}$ & $\begin{array}{c}\text { Densidad } \\
\text { aparente I } \\
\text { Apparent } \\
\text { density }\left(\mathrm{kg} / \mathrm{m}^{3}\right)\end{array}$ & $\begin{array}{l}\text { Densidad } \\
\text { aparente } \\
\text { compactada / } \\
\text { DR density } \\
\left(\mathrm{kg} / \mathrm{m}^{3}\right)\end{array}$ & $\begin{array}{c}\text { Contenido } \\
\text { de mortero I } \\
\text { Mortar content } \\
\text { (\%) }\end{array}$ \\
\hline \multicolumn{7}{|l|}{$\mathrm{ARH} / \mathrm{RCA}$} \\
\hline$A$ & 6.0 & 2307 & 2446 & 2678 & 1311 & 39 \\
\hline B & 4.7 & 2327 & 2440 & 2612 & 1329 & 32 \\
\hline \multicolumn{7}{|l|}{$\begin{array}{c}\text { Áridos naturales / Natural } \\
\text { aggregates }\end{array}$} \\
\hline AN / NA & 0.6 & 2671 & 2686 & 2713 & 1510 & - \\
\hline Arena I / Sand I & 0.7 & 2650 & 2670 & 2700 & - & - \\
\hline Arena II / Sand II & 1.6 & 2625 & 2665 & 2736 & - & - \\
\hline
\end{tabular}

\section{Composición de los AR}

Los ARH fueron sometidos a un análisis de constituyentes, hecho bajo las especificaciones prescritas en la norma UNE-EN 933-11:2009 (11).

El reciclado A está compuesto por un $89 \%$ de AN con mortero adherido y un $11 \%$ de AN limpio, no presentando impurezas de ningún tipo.

El reciclado $\mathrm{B}$ se compone de un $13 \%$ de material bituminoso, $1 \%$ de material cerámico, $56 \%$ de AN con mortero adherido y un $30 \%$ de AN limpio. Este árido no cumple con lo indicado en la Instrucción Española de Hormigón Estructural (12); sin embargo, se utiliza dado que uno de los objetivos de esta investigación es comprobar las propiedades del hormigón resultante usando áridos de diferentes procedencias.

Podemos notar, que la absorción de los ARH, comparada con la de los AN, es la propiedad que muestra la mayor variación respecto de las otras. La mayor absorción de los ARH se debe a la gran absorción que presenta el mortero adherido a éstos (7, 13-15). Resultados similares a los encontrados se han visto en diversas publicaciones

\section{RCA Composition}

The two types of recycled aggregates used in this investigation were subjected to a component classification analysis, following the specifications prescribed in UNE-EN 933-11:2009 (11).

Aggregate type $A$ presents no impurities and is composed by $89 \%$ of $N A$ with attached mortar, and $11 \%$ of clean NA.

Aggregate type $B$ presents an important quantity of bituminous material with a $13 \%, 1 \%$ of ceramic materials, $56 \%$ of NA with attached mortar and $30 \%$ of clean NA. Aggregate type $B$ does not comply with the actual Spanish Instruction for Structural Concrete (12); however, as one of the aims of this investigation is to check on the properties of the resultant concrete using different aggregates, it was used.

As it can be noticed, absorption in RCA is the property showing the biggest change among the others, when compared to NA. The higher absorption on RCA is due to the high absorption of the mortar attached to it (7, 1315). Similar results as the ones encountered have been found in different publications (7, 16-19). This explains 
(7, 16-19). Esto explica el mayor requerimiento de agua que tienen las mezclas de HAR.

La caracterización física fue llevada a cabo siguiendo las especificaciones prescritas por UNE-EN 1097-6:2001 (20) y ASTM C 29/C 29M - 09 (21). La determinación de la cantidad de mortero adherido a los ARH fue llevada a cabo mediante la metodología presentada a continuación, dado que, al día de hoy, no presenta normalización alguna.

\section{Contenido de mortero adherido}

Es importante mencionar la determinación del mortero adherido a los AR gruesos, dada su importancia respecto del nuevo método de dosificación, por su influencia en las propiedades del hormigón resultante, y por las dificultades que supone su determinación.

Los áridos fueron sometidos a diferentes metodologías para la obtención de esta característica. Ciclos de hielodeshielo con agua natural, ciclos de hielo-deshielo con una solución de sulfato sódico (22), disolución mediante ácido clorhídrico, y choque térmico (23).

Las metodologías de hielo-deshielo necesitaron de mucho tiempo debido a la cantidad de ciclos para la obtención de resultados. El uso de ácido clorhídrico provocó la desintegración parcial del árido dada su composición. Por lo anterior, la metodología de choque térmico fue elegida.

La metodología de choque térmico consistió en sumergir una muestra de AR en agua, durante un periodo de quince minutos para así lograr su saturación (24), tras lo cual fue introducida en una mufla a una temperatura de $500{ }^{\circ} \mathrm{C}$ por dos horas. El objetivo de esto es crear tensiones en el interior de las partículas de AR, mediante la rápida evaporación de agua. Tras el periodo de dos horas dentro de la mufla, la muestra es arrojada en agua fría, para crear nuevamente tensiones debidas al choque térmico. El objetivo de inferir estas tensiones es desmoronar el mortero adherido y separarlo de la superficie del AN, para así conseguir la división de las dos fases del AR.

Una vez separado el mortero adherido, se pesan las dos fases y se determina el porcentaje correspondiente al mortero adherido.

\subsection{Diseño de mezclas}

La primera parte de la investigación se llevó a cabo con un total de ocho mezclas, diseñadas con el propósito de verificar el nuevo método propuesto. Por una parte, se usó la metodología propuesta por la ACI (25), para elaborar mezclas con un $100 \%$ de reemplazo de AN por ARH (A y $B)$. Las mezclas fueron diseñadas con una relación agua/ cemento (a/c) igual a 0,45 y 0,6 , y las dosificaciones the higher water requirements on recycled concrete mixes.

The physical characterization was obtained following the specifications prescribed in UNE-EN 1097-6:2001 (20) and ASTM C 29/C 29M - 09 (21). The mortar content determination of the RCA does not have a standard at the present, so the following methodology was carried out.

\section{Attached mortar content}

It is worth noting the determination of attached mortar in recycled coarse aggregates, due to its importance for the new mix design, because of its significance on the properties of the resultant concrete, and because of the encountered difficulties on its obtaining.

The aggregates were submitted to different methodologies in order to obtain this characteristic. Freezing and thawing with natural water, freezing and thawing with a sodium sulphate solution (22), hydrochloric acid dissolution and thermal attack (23) were tried.

Freezing and thawing methodologies required too much time due to the amount of cycles needed to obtain results. Hydrochloric acid provoked partial disintegration of the aggregates due to its composition. Because of all this, thermal attack methodology was chosen.

Thermal attack methodology consisted on submerging a sample of the recycled aggregate in water, for fifteen minutes in order to achieve its saturation (24), and then placing it inside a $500{ }^{\circ} \mathrm{C}$ preheated muffle for two hours. Its purpose is to create internal stresses within the particles through the rapid evaporation of water. After the two hours inside the muffle, the sample is then thrown in cold water in order to create stresses by the thermal shock. These stresses purpose is to crumble down the attached mortar and separate it from the aggregate, consequently achieving a good division of the two phases of the recycled aggregate.

Once the attached mortar is separated, the two phases are weighted and the mortar content is determined.

\subsection{Mixes design}

For the first part of the investigation, a total of eight different mix designs were prepared in order to verify the proposed method. On one hand, the ACI mix design for normal concrete (25) was used to prepare concrete mixes with $100 \%$ replacement of the natural coarse aggregate by the recycled ones ( $A$ and $B$ ). The designed mixes were calculated with a water/cement $(W / c)$ ratio of 0.45 and 
fueron obtenidas usando la densidad del $A R H$, tal y como se recomienda en el informe ACI 555R-01 (6). Por otra parte, utilizando el nuevo método $\operatorname{EMV}(26,5)$ se han elaborado mezclas utilizando los reciclados $A$ y $B$, también con relaciones a/c de 0,45 y 0,6 .

En la segunda parte de la investigación se elaboraron un total de seis mezclas. Primero se han diseñado mezclas de hormigón convencional, utilizando un $100 \%$ de $\mathrm{AN}$, mediante la metodología propuesta por Bolomey (1), con el objetivo de obtener un hormigón patrón. Luego, usando la metodología propuesta por Bolomey, se diseñó un hormigón con un reemplazo de un $20 \%$ en peso de AN por ARH, con el propósito de obtener una mezcla que cumpliese con las prácticas habituales y recomendadas de diseño de HAR. Finalmente, una mezcla con un $20 \%$ de reemplazo de AN por ARH fue diseñada, utilizando una adaptación del nuevo método a la metodología de Bolomey. El reemplazo de un $20 \%$ fue elegido para cumplir con las recomendaciones propuestas por la Instrucción Española de Hormigón Estructural (12). Todas las mezclas han sido elaboradas utilizando relaciones a/c de 0,45 y 0,6 , y utilizando, en todos los casos, AN y ARH grueso, y árido fino natural.

Las mezclas de la primera parte de la investigación han sido elaboradas utilizando aditivo SP e IA. Las mezclas de la segunda parte han sido elaboradas utilizando únicamente aditivo SP para la relación a/c 0,45.

Al dosificar con la metodología EMV, siempre ha habido que aumentar la cantidad de SP para alcanzar una trabajabilidad semejante a la obtenida con los métodos de dosificación convencionales. Esto es debido a la reducción de mortero fresco que resulta al aplicar el método EMV. Esta reducción de la trabajabilidad no es perceptible, en el caso de las mezclas de HAR diseñadas convencionalmente y con el nuevo método, cuando se aplica la limitación de uso de árido reciclado al $20 \%$.

Las mezclas basadas en la metodología de la ACI, se han denominado mostrando, en primer lugar, el método de diseño utilizado (ACI o EMV), seguido del tipo de ARH ( $A$ o B), y finalizando con la relación a/c utilizada. Las mezclas basadas en Bolomey, muestran en primer lugar el método utilizado para su diseño (BOL CON para mezclas diseñadas convencionalmente utilizando Bolomey, y BOL EMV para mezclas elaboradas con la adaptación del nuevo método a Bolomey), seguido del porcentaje de reemplazo de $\mathrm{ARH}, \mathrm{y}$ terminando con la relación a/c adoptada.

Las densidades teóricas mostradas en la Tabla 2 han sido calculadas teniendo en cuenta la absorción de agua de los áridos, y un $6 \%$ de aire ocluido en el caso de las basadas en ACI.
0.6, and the mix proportions were obtained using the density of the recycled aggregate as recommended in ACI 555R-01 Report (6). On the other hand, by using the EMV method $(26,5)$, other mixes were prepared using recycled aggregates $A$ and $B$, and calculated with 0.45 and $0.6 \mathrm{w} / \mathrm{c}$ ratios as well.

For the second part of the investigation, a total of six mix designs were made. Firstly, using Bolomey methodology (1), a conventional mix with $100 \%$ NA was prepared in order to obtain a concrete used as base of comparison. A mix using Bolomey methodology and a simple weight replacement, as used in normal practices, of $20 \%$ of the $N A$ by the recycled ones, was prepared in order to obtain results from common practices. Finally, another mix design was elaborated, achieving also a $20 \%$ weight replacement of the NA by the recycled ones, by using an adaptation of the new mix design to Bolomey methodology. The $20 \%$ replacement was chosen in order to comply with the recommendations cited in the Spanish Instruction for Structural Concrete (12). All the mixes were prepared with both 0.45 and $0.6 \mathrm{w} / \mathrm{c}$ ratios, and comprising only natural and recycled coarse aggregates, and natural fine aggregates.

ACI based mixes, included the use of a SP additive and an $A E$. Bolomey based mixes only used a SP additive on the $0.45 \mathrm{w} / \mathrm{c}$ ratio.

On all the occasions, when designing with the EMV methodology, an increment on the amount of SP additive has been applied in order to achieve similar workability as to the conventional design methods. This is due to the reduction on the fresh mortar amount that the EMV methodology implies. This workability reduction is not perceptible, in the cases of the RAC mixes whether designed conventionally or with the new method, when the $20 \% R A$ limitation is applied.

ACI based mixes designation show the proportioning method in the beginning (ACI or EMV), followed by the recycled aggregate type ( $A$ or $B)$, and finally their $w / c$ ratio. Bolomey based mixes show the proportioning method in the beginning (BOL CON for Bolomey using conventional methods and BOL EMV for Bolomey with the EMV adaptation), followed by the percentage of RCA replacement, and finally their $w / c$ ratio.

Theoretical densities shown in Table 2 have been calculated taking into account the water absorption of the aggregates, and a $6 \%$ of air content in the case of the ACI mixes. 
Tabla 2 / Table 2

Resumen de dosificaciones de mezclas ACI y Bolomey.

$A C I$ and Bolomey based mixes proportioning summary

\begin{tabular}{|c|c|c|c|c|c|c|c|c|c|c|c|c|c|c|}
\hline & ID & $\begin{array}{c}\text { ARH I } \\
R C A \\
(\%)\end{array}$ & $\begin{array}{c}\text { Agua I } \\
\text { Water } \\
\text { (kg) }\end{array}$ & $\begin{array}{c}\text { Cemento } \\
\text { / Cement } \\
\text { (kg) }\end{array}$ & $\begin{array}{l}a / c / \\
w / c\end{array}$ & $\begin{array}{l}\text { Árido fino / } \\
\text { Fine } \\
\text { Aggregate } \\
\text { (kg) }\end{array}$ & $\begin{array}{c}\text { Árido } \\
\text { grueso / } \\
\text { Coarse } \\
\text { aggregate } \\
(\mathrm{kg})\end{array}$ & $\begin{array}{c}\text { ARH-A I } \\
R C A-A \\
(\mathrm{~kg})\end{array}$ & $\begin{array}{c}\text { ARH-B / } \\
R C A-B \\
(\mathbf{k g})\end{array}$ & $\begin{array}{l}\text { IA I } \\
A E \\
\text { (gr) }\end{array}$ & $\begin{array}{l}S P I \\
S P \\
(\mathrm{gr})\end{array}$ & $\begin{array}{l}\text { Aire } \\
\text { I Air } \\
(\%)\end{array}$ & $\begin{array}{c}\text { Asiento } \\
\text { I Slump } \\
\text { (cm) }\end{array}$ & $\begin{array}{c}\text { Densidad } \\
\text { teórica / } \\
\text { Theoretical } \\
\text { density }(\mathbf{k g} / \\
\left.\mathbf{m}^{3}\right)\end{array}$ \\
\hline \multirow{8}{*}{$\overline{0}$} & ACl-A (0.45) & 100 & 184 & 409 & 0.45 & 752 & - & 786 & - & 82 & 1227 & 9 & 15 & 2183 \\
\hline & EMV-A (0.45) & 65 & 140 & 311 & 0.45 & 577 & 421 & 782 & - & 62 & 2176 & 8 & 10 & 2284 \\
\hline & ACI-B (0.45) & 100 & 184 & 409 & 0.45 & 746 & - & - & 798 & 82 & 1227 & 8 & 17 & 2179 \\
\hline & EMV-B (0.45) & 68 & 145 & 323 & 0.45 & 600 & 369 & - & 788 & 65 & 1939 & 5 & 6 & 2268 \\
\hline & $\mathrm{ACl}-\mathrm{A}(0.6)$ & 100 & 184 & 307 & 0.6 & 839 & - & 786 & - & 61 & 613 & 9 & 17 & 2169 \\
\hline & EMV-A (0.6) & 65 & 140 & 233 & 0.6 & 644 & 421 & 782 & - & 47 & 1632 & 9 & 9 & 2274 \\
\hline & ACl-B (0.6) & 100 & 184 & 307 & 0.6 & 833 & - & - & 798 & 61 & 613 & 9 & 12 & 2165 \\
\hline & EMV-B (0.6) & 68 & 145 & 242 & 0.6 & 669 & 369 & - & 788 & 48 & 1454 & 5 & 5 & 2257 \\
\hline \multirow{6}{*}{ 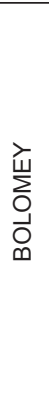 } & $\begin{array}{l}\text { BOL CON } \\
0 \%(0.45) \\
\end{array}$ & 0 & 184 & 409 & 0.45 & 796 & 1085 & - & - & - & 1500 & - & 15 & 2493 \\
\hline & $\begin{array}{c}\text { BOL CON } \\
20 \%(0.45)\end{array}$ & 20 & 184 & 409 & 0.45 & 796 & 842 & 210 & - & - & 850 & - & 14 & 2471 \\
\hline & $\begin{array}{c}\text { BOL EMV } \\
20 \%(0.45)\end{array}$ & 20 & 169 & 376 & 0.45 & 732 & 941 & 235 & - & - & 2100 & - & 15 & 2484 \\
\hline & $\begin{array}{c}\text { BOL CON } 0 \% \\
(0.6)\end{array}$ & 0 & 184 & 307 & 0.60 & 958 & 1010 & - & - & - & - & - & 13 & 2480 \\
\hline & \begin{tabular}{|l|} 
BOL CON \\
$20 \%(0.6)$ \\
\end{tabular} & 20 & 184 & 307 & 0.60 & 914 & 819 & 205 & - & - & - & - & 8 & 2461 \\
\hline & $\begin{array}{l}\text { BOL EMV } \\
20 \%(0.6)\end{array}$ & 20 & 171 & 286 & 0.60 & 892 & 876 & 219 & - & - & - & - & 7 & 2477 \\
\hline
\end{tabular}

\subsection{Combinación de áridos y granulometrías}

A continuación se muestran las composiciones granulométricas de los áridos y de las combinaciones utilizadas.

En las Figuras 1 a 4 se puede apreciar el efecto que tiene la aplicación del nuevo método sobre todas las combinaciones mostradas respecto del método ACI. La reducción de la parte fina hace que todas las curvas EMV se posicionen por debajo de las ACI. Por otra parte, se hace notar la falta de un árido medio-grueso para así rellenar la parte comprendida alrededor del tamaño $8 \mathrm{~mm}$, lo que crea una discontinuidad en la curva.

Lo anterior podría provocar segregación en las mezclas más esto no se ha hecho efectivo a la hora de la fabricación del hormigón.

En el caso de las mezclas EMV el efecto de la discontinuidad se ve más afectado por la reducción de la parte fina producto de la aplicación del método, razón por la cual se ha hecho necesario un incremento de la cantidad de aditivo SP.

En las Figuras 5 y 6 vemos el ajuste granulométrico logrado tras la combinación de las diferentes fracciones de áridos para las mezclas de hormigón basadas

\subsection{Aggregates combination and grading}

Aggregates grading and utilized combinations are shown next.

On Figures 1 to 4, the effect of using the EMV method when compared to the ACI mixes on the aggregates combinations is observed. The fine part reduction due to the EMV methodology application makes all of its curves to be placed bellow the ACI ones. On the other hand, it can be noticed that there is a medium-coarse aggregate scarcity in order to fill the part surrounding the $8 \mathrm{~mm}$ size which creates a gap on the curve.

This could turn into the mixes segregation but during the whole investigation such problem did not occur.

In the EMV mixes case, the effect of the gap is emphasized by the fine part reduction that the method implies and because of this, an increment on the amount of $S P$ additive was needed.

Figures 5 and 6 show the curves adjustment accomplished after the different aggregates fractions combination for the Bolomey based mixes. Overall, good approaches to 


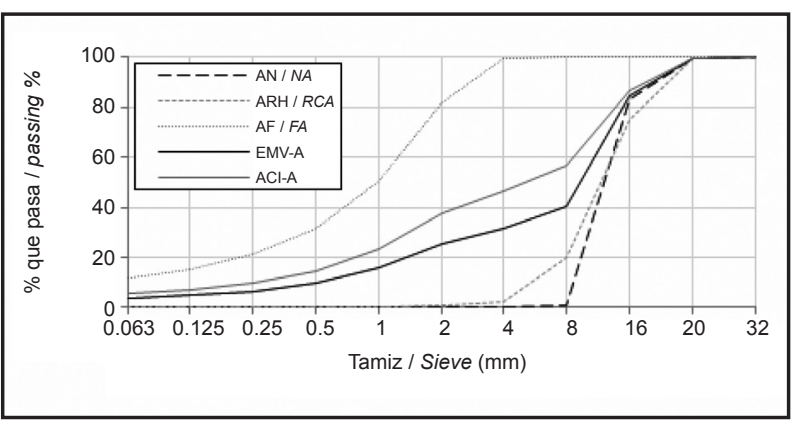

Figura 1. Mezclas ACI-EMV con a/c $=0,45$ y ARH-A. Figure 1. ACI-EMV mixes with $w / c=0.45$ and $R C A-A$.

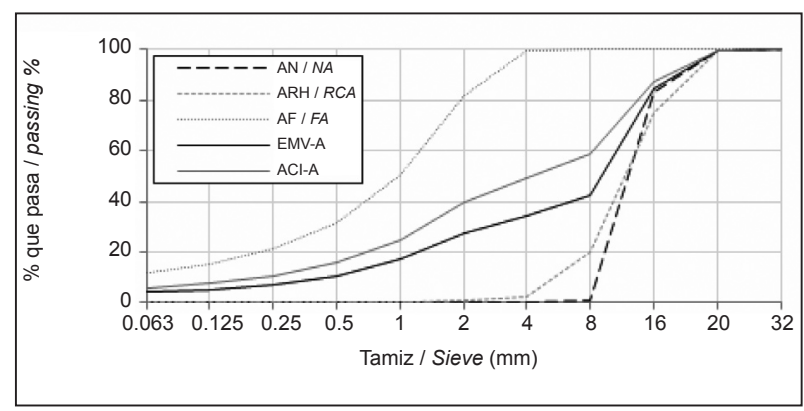

Figura 3. Mezclas ACI-EMV con a/c $=0,6$ y ARH-A Figure 3. ACI-EMV mixes with $w / c=0.6$ and $R C A-A$.

en la metodología Bolomey. En general se logran buenos acercamientos a la curva de referencia con la excepción del tamaño situado alrededor de los $8 \mathrm{~mm}$, que, como se ha comentado en el párrafo anterior, provoca una discontinuidad en la curva, pudiendo así afectar aspectos relacionados con la docilidad de las mezclas.

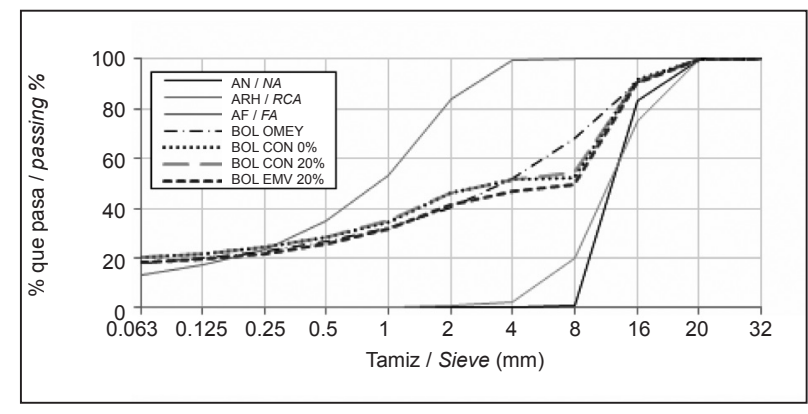

Figura 5. Mezclas basadas en Bolomey con $\mathrm{a} / \mathrm{c}=0,45$. Figure 5. Bolomey based mixes with $w / c=0.45$.

Las mezclas con relación a/c 0,45 diseñadas convencionalmente muestran una mejor compensación de áreas que la diseñada con el método EMV. Aún así, tanto en las mezclas diseñadas convencionalmente como en las diseñadas con el nuevo método se ha utilizado un aditivo SP de manera de lograr una trabajabilidad adecuada.

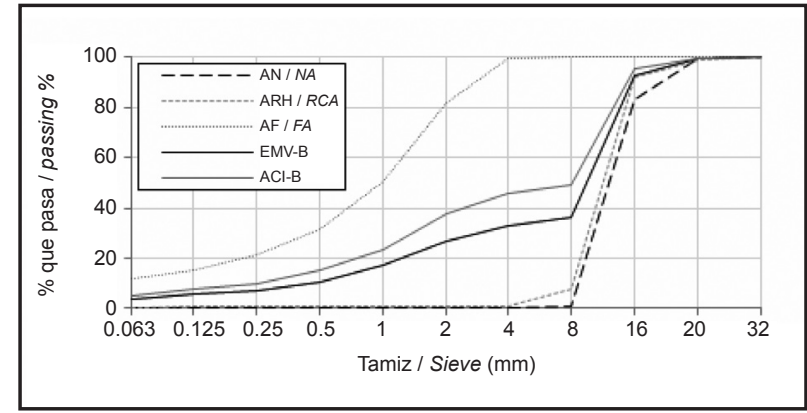

Figura 2. Mezclas ACI-EMV con $\mathrm{a} / \mathrm{c}=0,45$ y ARH-B. Figure 2. ACI-EMV mixes with $w / c=0.45$ and $R C A-B$.

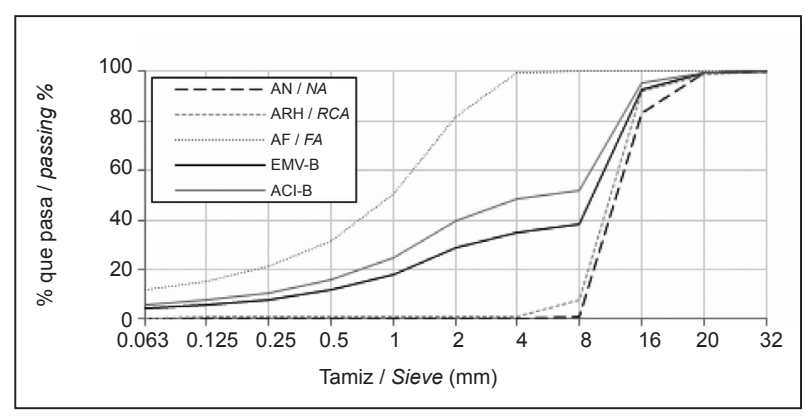

Figura 4. Mezclas ACI-EMV con a/c $=0,6$ y ARH-B.

Figure 4. ACI-EMV mixes with $w / C=0.6$ and $R C A-B$.

the reference curve are achieved with the exception of the $8 \mathrm{~mm}$ size surroundings, which, as it was previously mentioned, provokes a gap in the curve, and so probably affects such aspect as the workability.

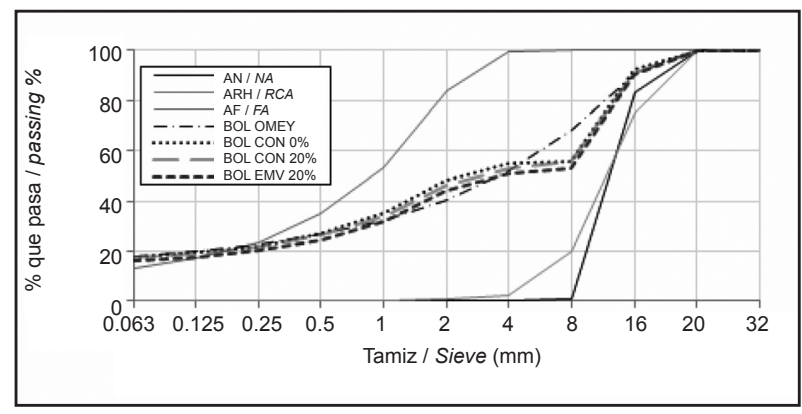

Figura 6. Mezclas basadas en Bolomey con a/c=0,6. Figure 6. Bolomey based mixes with $w / c=0.6$.

Conventionally designed mixes with a $0.45 \mathrm{w} / \mathrm{c}$ ratio show better area compensation than the ones designed with the EMV method. Even though this, a SP additive has been used in both mixes in order to achieve the desired workability. 
Las mezclas con relación a/c 0,6 muestran una mejor compensación de áreas que las con relación a/c 0,45. En el caso de las mezclas diseñadas mediante el método EMV, la reducción de la parte fina se compensa con el uso de AN, por lo que los hormigones se pueden fabricar con una menor demanda de agua. Lo anterior también nos hace inferir que se lograrían mejorías respecto al comportamiento mecánico.

\subsection{Procedimiento de elaboración del hormigón}

Tanto las mezclas diseñadas con la metodología propuesta por la ACI como las de Bolomey, han sido preparadas de igual manera.

Una mezcladora Collomatic XM de accionamiento forzado, de la compañía Collomix, ha sido usada para la fabricación del hormigón. Una práctica común y recomendada, a la hora de elaborar mezclas de HAR, es sumergir los áridos en agua antes del mezclado (6), para evitar problemas relacionados a su alta absorción; sin embargo, al hacer esto, la relación a/c efectiva se vuelve difícil de controlar y, por tanto, los resultados finales se podrían distorsionar. Para evadir esto, y con el objetivo de mantener la relación a/c inalterada y aislar los problemas de asentamiento respecto de este factor, todos los áridos fueron pesados y guardados en bidones herméticos, 24 horas antes del mezclado, junto con el agua necesaria para obtener su condición saturada con la superficie seca. Los bidones fueron agitados intensamente, tras poner los áridos dentro de ellos y justo antes del hormigonado, para asegurar una distribución uniforme del agua en los áridos.

Tras tener todos los componentes debidamente preparados, fueron depositados en la mezcladora, comenzando con los áridos gruesos (AN y ARH), siguiendo con el árido fino, el cemento y finalmente el agua. Los aditivos fueron introducidos dos minutos antes de que el mezclado terminase. Fueron medidas la temperatura y la humedad durante todo el proceso. La temperatura del hormigón también fue medida.

Las probetas de hormigón se dejaron en el laboratorio por un día, tapadas con una arpillera húmeda para así evitar la evaporación de agua, y luego fueron desmoldadas y llevadas a una cámara con humedad controlada hasta el día de ensayo.

\subsection{Propiedades del hormigón fresco y endurecido}

La campaña experimental incluyó el ensayo de asentamiento (27), contenido de aire (28), densidades de hormigón fresco y endurecido $(28,29)$, resistencia a compresión
$0.6 \mathrm{w} / \mathrm{c}$ ratio mixes show better area compensation than the $0.45 \mathrm{w} / \mathrm{c}$ ratio ones. In the case of the EMV method, the fine part reduction is compensated with NA and so the mixes can be elaborated using less water. This issue makes us deduce that there should be improvements on the mechanical behavior.

\subsection{Concrete elaboration procedure}

The same preparation and mixing procedure was used for both ACI based and Bolomey based concretes.

A Collomatic XM forced action mixer, from Collomix Co., was used for the mixes elaboration. A common and recommended practice when elaborating mixes with recycled aggregates is to submerge the aggregates in water (6) before the mixing process, in order to avoid problems due to their higher water absorption, but, by doing this, the effective $w / c$ ratio turns difficult to control and, consequently, the final results could be distorted. In order to avoid problems related to varying values in the $w / c$ ratio content, and to keep this value unaltered during the fabrication process, and so isolate slump values problems from it, all the aggregates were weighted and stored in hermetic drums, 24 hours before mixing, together with the exact amount of water needed to achieve their saturated surface-dry condition. The hermetic drums were agitated intensively, after placing the aggregates with their amount of absorption water into them and prior to mixing, in order to guarantee a uniform distribution of the absorption water within the aggregates.

After having all the components properly prepared, they were deposited into the mixer drum, starting with the coarse aggregates (RCA and NA) and following with the fine aggregates, the cement and finally the water. Additives were introduced two minutes before the mixing stopped. Room temperature and humidity were measured during the whole process. Concrete temperature was also measured.

The concrete specimens were stored for one day in the laboratory with a wet fabric on top of them, thus, avoiding the water evaporation. After the first day, the specimens were unmolded and taken into a relative humidity controlled chamber until testing.

\subsection{Fresh and hardened concrete properties}

The experimental campaign included the slump measurement (27), air content (28), fresh and hardened densities $(28,29)$, compressive strength (30) and static modulus 
(30) y módulo elástico estático (31). Este último ensayo, corresponde al módulo secante, y fue ejecutado tomando en cuenta una carga inicial de $0,5 \mathrm{~N} / \mathrm{mm}^{2}$ y una carga máxima igual a la tercera parte de la resistencia a compresión obtenida, una velocidad de ensayo de 0,5 $\pm 0,2$ $\mathrm{N} / \mathrm{mm}^{2}$, y registrando las deformaciones en los límites de carga mencionados. Los ensayos de hormigón endurecido fueron hechos a la edad de 28 días.

\section{RESULTADOS Y DISCUSIÓN}

\subsection{Propiedades del hormigón fresco}

\section{Asentamiento}

Como se puede ver en la Figura 7 los asentamientos de las mezclas basadas en la metodología $\mathrm{ACI}$, diseñadas con el método EMV, fueron menores que las hechas con el método convencional. Esto puede ser producto de las diferencias en los contenidos de agua entre ellas. Las mezclas EMV utilizaron alrededor de 40 litros menos de agua por metro cúbico que las convencionales. Otra razón a tener en consideración es la cantidad de árido fino y cemento, que en el caso de las mezclas EMV, también se redujo. Las mezclas EMV-B muestran los menores valores de asentamientos, lo que se corregiría con el uso de una mayor cantidad de aditivo.

Los asentamientos de las mezclas basadas en Bolomey fueron similares en el caso de la relación a/c 0,45. En el caso de los hormigones con relación a/c 0,6, que han sido confeccionados sin el uso de aditivo, la mezcla BOL CON $0 \%$ presentó un valor de asentamiento mayor que las $\mathrm{BOL}$ CON $20 \%$ y BOL EMV $20 \%$. Los resultados hacen deducir que las diferencias entre los asentamientos son producto del uso de AR y pueden ser corregidos mediante el uso de aditivo SP. En todos los casos, los asentamientos se encontraron dentro de rangos normales. Los resultados se muestran en la Figura 8.

Las probetas fabricadas en este estudio se compactan correctamente y no presentan huecos en ningún caso.

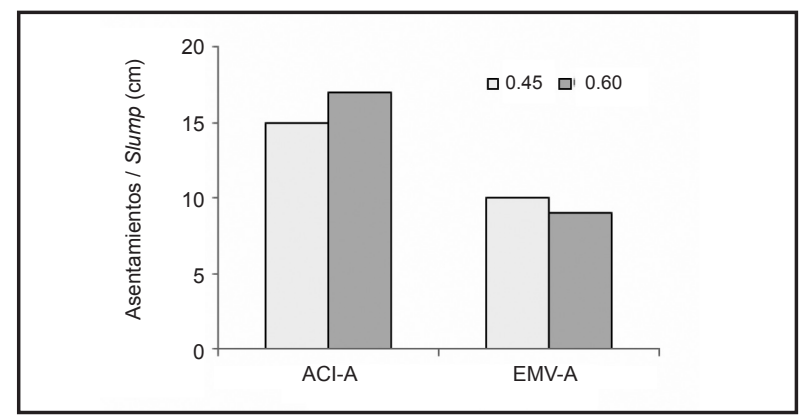

of elasticity (31). This last test, corresponds to the secant modulus, and is executed taking into account an initial load equal to $0.5 \mathrm{~N} / \mathrm{mm}^{2}$ and a peak load equal to the third part of the obtained compressive strength, a test velocity of 0.5 $\pm 0.2 \mathrm{~N} / \mathrm{mm}^{2}$, and taking note of the deformations on the commented load levels. The hardened concrete tests were done when the concrete was 28 days old.

\section{RESULTS AND DISCUSSION}

\subsection{Fresh concrete properties}

\section{Slump}

As it can be seen in Figure 7 the slumps of all ACI based mixes, prepared with EMV method, were lower than those made with the conventional method. This may be due to the differences in the water content of them. EMV mixes used around 40 litres less by cubic meter than the conventional ones. Another reason to have into consideration is the amount of fine aggregate which, in the case of EMV mixes, was also reduced. EMV-B mixes show the lower values on this property which could be corrected by using higher amounts of additive.

Bolomey based mixes slumps were similar in the case of the $0.45 \mathrm{w} / \mathrm{c}$ ratio. For the $0.6 \mathrm{w} / \mathrm{c}$ ratio mixes, which have been elaborated without using additive, the slump of the BOL CON 0\% mix was higher than BOL CON $20 \%$ and BOL EMV 20\% mixes. The results make us deduce that the slump differences are due to the use of $R A$ and could be corrected by using SP additive. In all cases the slumps results were into acceptable ranges. These results are shown in Figure 8

All concrete specimens were properly compacted and no surface voids have been observed.

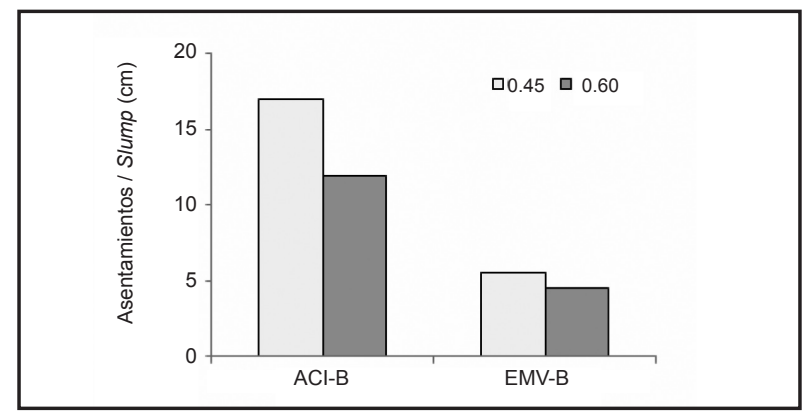

Figura 7. Asentamientos de las mezclas basadas en ACI.

Figure 7. ACI based mixes slump. 


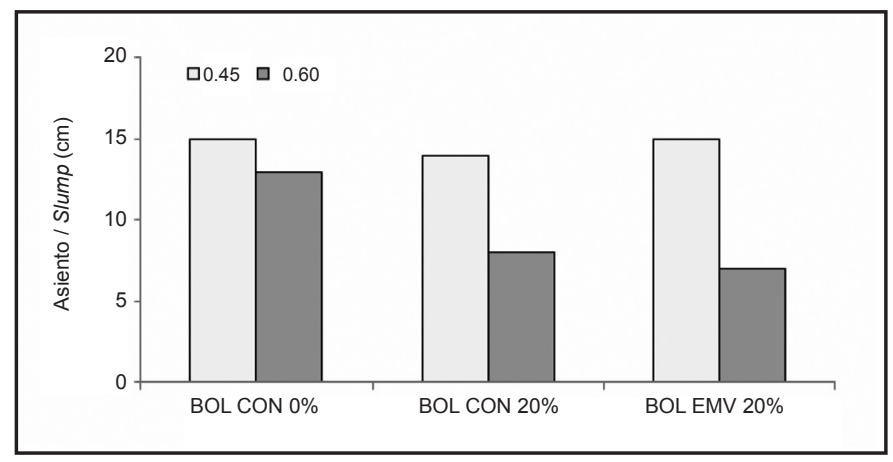

Figura 8. Asentamientos de las mezclas basadas en Bolomey. Figure 8. Bolomey based mixes slump.

\section{Contenido de aire}

Como fue mencionado anteriormente, un aditivo IA fue utilizado, con el propósito de obtener características similares a las del estudio original, en el caso de las mezclas basadas en la ACI. El uso de tal aditivo es comprensible, dadas las condiciones de ciclos hielo-deshielo que afectan a la zona geográfica donde se realizó el estudio de referencia.

Tanto para la relación a/c 0,45 como para la 0,6, se utilizó una cantidad de aditivo igual a $0,02 \%$, en términos del peso del cemento por metro cúbico. El contenido de aire objetivo en el diseño fue un $6 \%$. Las cantidades de aditivo IA se muestran en la Tabla 2.

Los resultados mostrados en la Figura 9 muestran altos valores en esta propiedad, a excepción de la mezcla EMVB. Tales efectos pueden deberse a la propia naturaleza de los áridos y a las proporciones en las que se mezclan.

La inclusión de aire en un hormigón causa diversos efectos en sus propiedades, como la reducción de sus resistencias mecánicas, una mejor trabajabilidad, y mejorías en aspectos relacionados a la durabilidad (1). Estos asuntos serán mencionados en algunas de las propiedades del hormigón obtenido.

\section{Air content}

As mentioned above, an air entraining agent was used in order to achieve comparable characteristics to the original investigation in the ACI based concrete mixes. Because of the geographic location of the original investigation, where there are freeze and taw cycles, it is understandable the use of such additives.

For both 0.45 and $0.6 \mathrm{w} / \mathrm{c}$ ratios, an amount of $0.02 \%$, in terms of the weight of total cement per cubic meter, was the used amount of additive. The target air content on these mixes was $6 \%$. The quantities are shown in Table 2.

Except in the case of the EMV-B mixes, as shown in Figure 9, the results clearly show high values in this property. Such values may be due to the aggregates nature and their mix proportions.

The air content inclusion in a concrete causes different effects on its properties such as reductions on its mechanical resistances, better workability and better durability properties (1). These issues will be addressed in some of the properties of the obtained concrete.
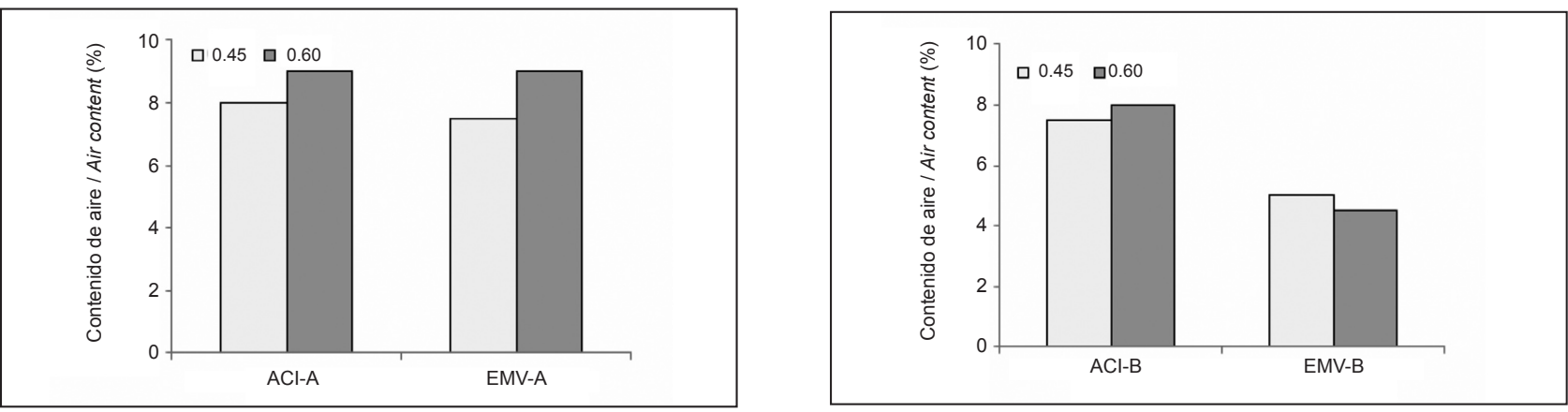

Figura 9. Contenido de aire en mezclas basadas en ACI. Figure 9. ACI based mixes air content. 


\section{Densidad del hormigón fresco}

Junto con la medición de aire ocluido, en las mezclas ACI, se obtuvieron las densidades en fresco, usando el recipiente del medidor de aire.

La densidad de la mezcla EMV-A fue un 5,4\% mayor que la ACI-A para la relación a/c 0,45, y un 5,5\% mayor en la relación a/c 0,6. La densidad de la mezcla EMV-B fue un $6,9 \%$ mayor que la ACI-A para la relación a/c 0,45, y un $8,8 \%$ mayor en la relación a/c 0,6, mostrando las mayores diferencias respecto de las otras muestras. Los resultados se muestran en la Figura 10.

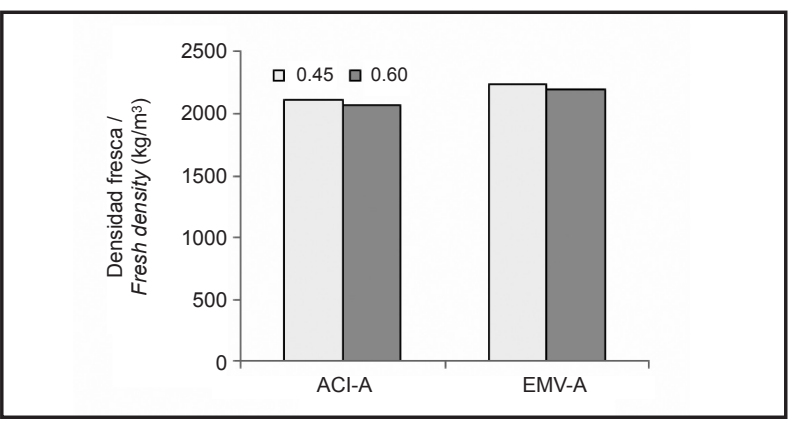

\section{Fresh concrete density}

Together with the air content measurement, fresh densities were obtained using the concrete container part of the air meter device, for the ACI based mixes.

EMV-A mix density was $5.4 \%$ higher than the ACI-A mix in the $0.45 \mathrm{w} / \mathrm{c}$ ratio, and $5.5 \%$ higher in the $0.6 \mathrm{w} / \mathrm{c}$ ratio. $E M V-B$ mix density was $6.9 \%$ higher than the $A C I-B$ mix in the $0.45 \mathrm{w} / \mathrm{c}$ ratio, and $8.8 \%$ higher in the $0.6 \mathrm{w} / \mathrm{c}$ ratio, thus showing the highest differences among all the mixes. The results are shown in Figure 10.

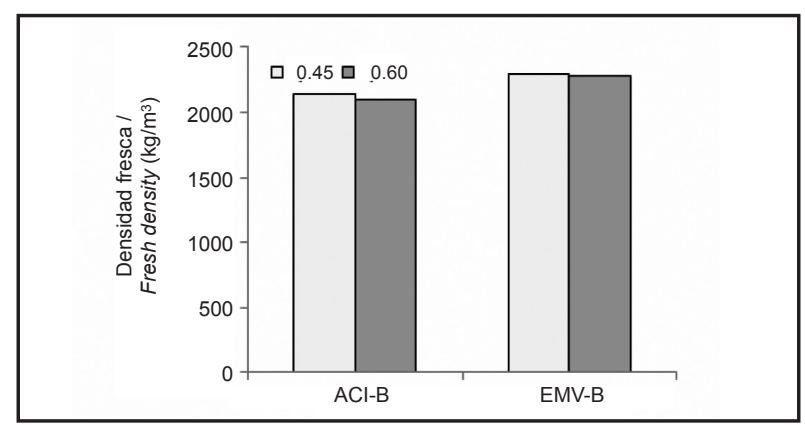

Figura 10. Densidades en fresco de las mezclas basadas en ACI. Figure 10. ACI based mixes fresh densities.

Como era de esperar, las densidades de las mezclas EMV fueron mayores que las de HAR convencionales, en parte, debido sus mayores contenidos de árido grueso y menores contenidos de mortero. Dado que el mortero posee una densidad menor que el AN, un cambio en las cantidades de éste supondrá un cambio en las densidades del hormigón. También, las densidades de las mezclas con reciclado $B$ fueron mayores que las elaboradas con reciclado $A$, en parte, debido a la mayor densidad del árido $\mathrm{B}$.

Otro aspecto de relevancia, es la correlación que Maier \& Durham encontraron entre el contenido de aire y la densidad. En algunas de sus mezclas, las mayores densidades fueron encontradas para los menores contenidos de aire (9). Si bien en este estudio las mezclas son diferentes, se puede apreciar una tendencia similar a la mencionada. Las mezclas EMV-B, respecto de las mezclas ACI-B, presentan las mayores diferencias en densidad y contenido de aire; esto, sumado al hecho de que la cantidad de AN fue mayor y el mortero menor, explica tales diferencias.

La diferencia existente entre las densidades reales de este apartado y las teóricas mostradas en la Tabla 2 se explica por las diferencias en los contenidos de aire reales y los adoptados por diseño.
As expected, the densities of the EMV mixes were higher than the conventional ones for $R A C$, in part, because of their higher amount of natural coarse aggregate and lower mortar content. As the mortar has lower density than NA, changing their quantities will suppose a change in the concrete density as well. Also, the densities of the mixes with recycled type $B$ aggregates were higher than those made with recycled type $A$ aggregates, in part, because of the first aggregate higher density.

Another issue to be mentioned is the correlation that was encountered between the densities and the air content of the mixes. Maier \& Durham found that, in some of their concrete mixes, the higher densities were encountered for the lower air contents (9). Although in this case the concrete mixes are all different, it can be noticed that the trend that Maier \& Durham encountered also appears. $E M V-B$ mixes presents the highest differences in the values of density with respect to the ACI-B mixes and also, the highest differences in their air contents; this, plus the fact that the amount of NA were higher and mortar contents were lower, for these mixes respectively, explains such differences in their fresh densities.

The existing difference between the real fresh densities and the theoretical ones shown in Table 2 can be explained due to the differences in the real air contents and the ones adopted by design. 


\subsection{Propiedades del hormigón endurecido}

\section{Densidad del hormigón endurecido}

Las mezclas ACI, como se puede apreciar en la Figura 11, presentan densidades mayores cuando se usa el nuevo método. Podemos apreciar la misma tendencia que la encontrada en las densidades en fresco, puesto que se mantienen las mismas proporciones de $\mathrm{AN}$, mortero y contenido de aire. Las densidades de los hormigones elaborados con reciclado $B$ son mayores que las elaboradas con reciclado $A$, dado el efecto combinado del contenido de aire y las densidades de los áridos, siendo estas últimas mayores en los reciclados $\mathrm{B}$. Las densidades de los hormigones con relación $\mathrm{a} / \mathrm{c}$ 0,45 son un poco superiores a las mezclas con relación a/c 0,6, dado el peso total de sus componentes.

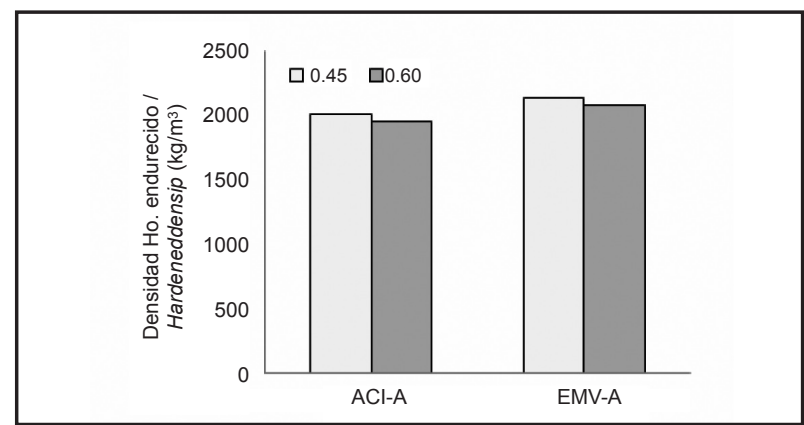

\subsection{Hardened concrete properties}

\section{Hardened concrete density}

For the ACI based mixes, as shown in Figure 11, the hardened density of the conventional recycled concrete is lower than the new proposed method. This property showed the same tendency as the fresh densities, because it maintains the same proportions on NA, total mortar content and entrained air. The densities of the concretes using recycled type $B$ aggregates are higher than those made with recycled type $A$, due to the combined effect of the amount of entrained air and the aggregates densities, in which $B$ aggregates are higher than a aggregates. The densities of the $0.45 \mathrm{w} / \mathrm{c}$ ratio mixes are slightly higher than those made with a $0.6 \mathrm{w} / \mathrm{c}$ ratio as well, due to the total weight of their components.

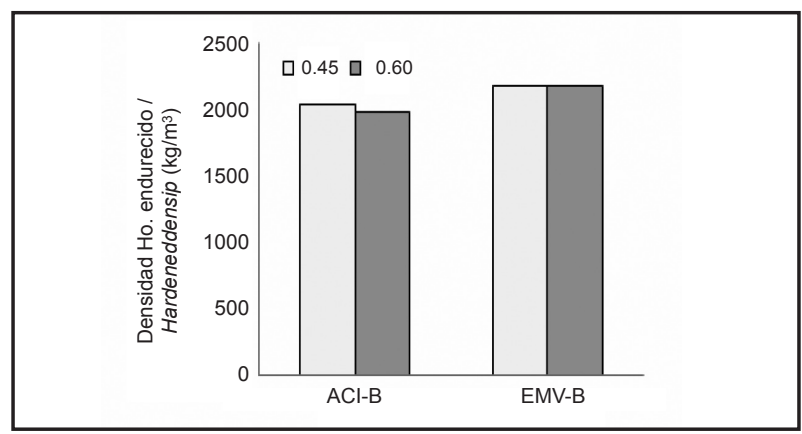

Figura 11. Densidades de hormigón endurecido de las mezclas basadas en ACI. Figure 11. ACI based mixes hardened densities.

Las densidades de hormigón endurecido muestran una reducción de alrededor de un $5 \%$, respecto de las densidades en fresco. La densidad de la mezcla EMV-A fue 6,7\% mayor que la ACI-A de relación a/c 0,45 y 7,1\% mayor en el caso de la relación a/c 0,6. La mezcla EMV-B fue 6,7\% mayor que la ACI-B de relación a/c 0,45 y 9,8\% mayor en el caso de la relación a/c 0,6, mostrando así, las mayores diferencias de entre todas las mezclas, tal como en el caso de las densidades en fresco.

Como se aprecia en la Figura 12, apenas se perciben diferencias en las densidades de las mezclas basadas en la metodología Bolomey. Esto se debe principalmente al bajo contenido de AR utilizado (20\%).

La diferencia entre estas densidades y las teóricas de la Tabla 2 se puede explicar por la metodología de cálculo, que tiene en cuenta un volumen de material necesario para llenar 1025 Its de volumen, y por el hecho de no tener en cuenta el aire ocluido en la mezcla, que podría variar considerablemente (32).
Hardened densities showed a reduction of about 5\% in terms of the fresh densities. EMV-A mix density was $6.7 \%$ higher than the $A C I-A$ mix in the $0.45 \mathrm{w} / \mathrm{C}$ ratio and $7.1 \%$ higher in the $0.6 \mathrm{w} / \mathrm{C}$ ratio. EMV-B mix density was $6.7 \%$ higher than the $A C I-B$ mix in the $0.45 \mathrm{w} / \mathrm{C}$ ratio and $9.8 \%$ higher in the $0.6 \mathrm{w} / \mathrm{C}$ ratio, thus showing the highest differences among all the mixes as in the fresh densities.

As it can be seen in Figure 12, Bolomey based mixes presented barely noticeable differences in their densities. This is due to the low RA content used (20\%).

The differences between these densities and the theoretical ones from Table 2 is explained by the design methodology, in which a volume of 1025 litters of material is needed, and also because in the design stage the air content in the mixes, which could considerably vary, is not taken into account (32). 


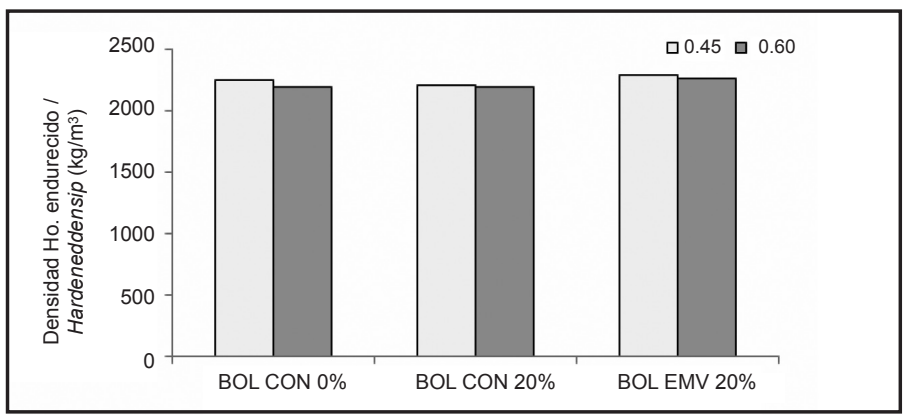

Figura 12. Densidades de hormigón endurecido de las mezclas basadas en Bolomey.

Figure 12. Bolomey based mixes hardened densities.

\section{Resistencias a compresión}

Las resistencias a compresión, de las mezclas $\mathrm{ACI}$, se han obtenido sobre probetas cúbicas de $10 \times 10 \times 10 \mathrm{~cm}$, y con el objetivo de mostrarlas en términos de probetas cilíndricas de $15 \times 30 \mathrm{~cm}$, se ha utilizado un factor de conversión igual a 0,8. Las mezclas basadas en Bolomey, se han obtenido sobre probetas cilíndricas de $10 \times 20 \mathrm{~cm}$, y con el objetivo de mostrarlas en cilíndricas de $15 \times 30 \mathrm{~cm}$, se ha utilizado un factor de conversión igual a 0,97 (1).

Varias publicaciones mencionan el hecho de que el aire ocluido en el hormigón reduce su resistencia a compresión en alrededor de un $5 \%$ por cada $1 \%$ de aire añadido ( 9 , 33-39). Maier \& Durham utilizaron una ecuación [1] para normalizar sus resistencias a compresión, para mostrarlas en base a un contenido de aire objetivo, obtenido del diseño teórico de la mezcla. Esta ecuación relaciona el contenido de aire objetivo y el real de la mezcla con la resistencia a compresión. La ecuación se muestra a continuación:

\section{Compressive strength}

The compressive strengths, of the ACI based mixes, have been obtained through $10 \times 10 \times 10 \mathrm{~cm}$ cubic specimens and in order to show them in terms of $15 \times 30 \mathrm{~cm}$ cylindrical specimens, a conversion coefficient equal to 0.8 has been used. The compressive strengths, of the Bolomey based mixes, have been obtained through $10 \times 20 \mathrm{~cm}$ cylindrical specimens, and in order to show them in terms of $15 \times 30 \mathrm{~cm}$ cylindrical specimens, a conversion coefficient equal to 0.97 has been used (1).

Several publications mention the fact that air entrainment in concrete reduces its strength in about 5\% for every $1 \%$ of air added (9, 33-39). Maier \& Durham used an equation [1] in order to normalize their compressive strength data, thus presenting it based on a target air content, which came from the theoretical design of the mixes. This equation relates the target air content and the real air content of the mix, with the concrete compressive strength, in order to obtain a normalized compressive strength. The equation is shown below:

$$
\frac{\mathrm{f}_{C}^{\prime} \mathrm{x}(1-0.05 * 6.5 \%)}{1-0.05 * \text { (Aire Medido / Measured Air) }}=\mathrm{f}_{C, \text { normalizada / normalized }}^{\prime}
$$

donde,

- $\mathrm{f}^{\prime}{ }_{\mathrm{C}} \mathrm{x}$, representa la resistencia a compresión obtenida

- $f_{c, \text { normalizadar representa la resistencia a compresión }}^{\prime}$ normalizada

- $\quad 0,05$, representa el $5 \%$ de reducción de resistencia por cada $1 \%$ de aire añadido

- $6,5 \%$, representa el contenido de aire objetivo de la investigación original

Para el caso de la primera parte de esta investigación, el contenido de aire objetivo ha sido un $6 \%$, por lo que, tras aplicar el factor de conversión de forma cada resistencia ha sido normalizada con esta fórmula. La Tabla 3 muestra las resistencias a compresión no modificadas y modificadas. where,

- $\mathrm{f}_{\mathrm{C}}{ }_{\mathrm{C}} \mathrm{x}$, represents the obtained compressive strength

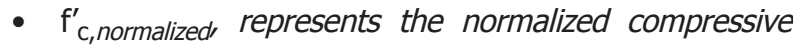
strength

- 0.05 represents the $5 \%$ strength reduction for every $1 \%$ of entrained air

- $6.5 \%$ represents the target air content of the former investigation

In the case of the first part of this investigation, the target air content was 6\%, so, after applying the specimen dimension factor every compressive strength has being normalized according to this formula. Table 3, shows the unmodified and modified compressive strengths. 
Tabla 3 / Table 3

Resistencias compresión modificadas en MPa, de las mezclas basadas en ACI, Normalized compressive strength in MPa, of the ACI based mixes.

\begin{tabular}{|c|c|c|c|c|c|c|c|c|}
\hline & \multicolumn{4}{|c|}{$\begin{array}{c}0.45 \\
\text { a/c - w/c }\end{array}$} & \multicolumn{4}{c|}{$\begin{array}{c}\text { 0.6 } \\
\text { a/c }-w / c\end{array}$} \\
\hline & ACl-A & EMV-A & ACI-B & EMV-B & ACI-A & EMV-A & ACI-B & EMV-B \\
\hline $\begin{array}{c}\text { Resistencias no modificadas / } \\
\text { Unmodified strengths }\end{array}$ & 39.5 & 41.1 & 41.4 & 49.0 & 25.9 & 26.4 & 27.6 & 35.6 \\
\hline $\begin{array}{c}\text { Resistencias modificadas / } \\
\text { Modified strengths }\end{array}$ & 36.8 & 36.9 & 37.1 & 36.6 & 26.4 & 26.9 & 25.8 & 25.7 \\
\hline
\end{tabular}

Los valores normalizados de resistencia a compresión, no muestran mayores cambios entre las diferentes metodologías adoptadas. Se llevó a cabo un análisis de varianza entre grupos, de acuerdo al tipo de árido y relación a/c utilizada, y no se encontraron diferencias significativas entre los valores obtenidos. Sin embargo, las resistencias a compresión de las mezclas EMV han sido obtenidas usando menor cantidad de cemento que las ACI.

Las mezclas EMV-A han sido diseñadas con $311 \mathrm{~kg} \mathrm{y}$ $233 \mathrm{~kg}$ de cemento, mientras que las ACI-A, con $409 \mathrm{~kg}$ y $307 \mathrm{~kg}$, para las relaciones a/c 0,45 y 0,6 respectivamente; esto representa una disminución de alrededor de un $24 \%$ en la cantidad de cemento por metro cúbico. Las mezclas EMV-B han sido diseñadas con $323 \mathrm{~kg}$ y $242 \mathrm{~kg}$ de cemento, mientras que las ACI-B, con $409 \mathrm{~kg}$ y $307 \mathrm{~kg}$, para las relaciones a/c 0,45 y 0,6 respectivamente; esto representa una disminución de alrededor de un $21 \%$ en la cantidad de cemento por metro cúbico. Además, las mezclas EMV utilizaron alrededor de 40 litros menos de agua que las ACI.

Los resultados de resistencias a compresión para la metodología ACI se muestran en la Figura 13.

Las mezclas basadas en la metodología de Bolomey alcanzaron similares resistencias, no mostrando diferencias significativas entre grupos. Las mezclas convencionales basadas en el método Bolomey, de relación a/c 0,45, se han diseñado con $409 \mathrm{~kg}$ de cemento y $184 \mathrm{~kg}$ de agua por metro cúbico, mientras que las diseñadas mediante la adaptación del método EMV, han utilizado $376 \mathrm{~kg}$ y $169 \mathrm{~kg}$, reduciendo así en alrededor de un 8\% las cantidades de cemento y agua. Las mezclas con relación a/c 0,6 , se diseñaron con $307 \mathrm{~kg}$ de cemento y $184 \mathrm{~kg}$ de agua por metro cúbico, mientras que las diseñadas mediante la adaptación del método usaron $286 \mathrm{~kg}$ y $171 \mathrm{~kg}$, reduciendo así en alrededor de un $7 \%$ la cantidad de cemento y agua.

Los resultados de resistencias a compresión para la metodología Bolomey son mostrados en la Figura 14.
These modified values show that there are no major changes between the different methodologies with respect to the compressive strength. An ANOVA test was carried out between groups, according to the aggregate type and the $w / c$ ratio used, and no significant differences were found. Nevertheless, the compressive strengths of the EMV method have been achieved using less cement than the conventional method.

EMV-A mixes were prepared using $311 \mathrm{~kg}$ and $233 \mathrm{~kg}$ of cement, while ACI-A mixes used $409 \mathrm{~kg}$ and $307 \mathrm{~kg}$, both for the 0.45 and $0,6 \mathrm{w} / \mathrm{c}$ ratios respectively, which represents about a $24 \%$ cement reduction per cubic meter. EMV-B mixes were prepared using $323 \mathrm{~kg}$ and $242 \mathrm{~kg}$ while ACI-B mixes used $409 \mathrm{~kg}$ and $307 \mathrm{~kg}$, both for the 0.45 and $0.6 \mathrm{w} / \mathrm{c}$ ratios respectively, which represents about a $21 \%$ cement reduction per cubic meter. Moreover, all the mixes using the EMV method used around 40 litres less water than the conventional method.

The compressive strength results for the ACI based mixes are shown in Figure 13.

Bolomey based mixes achieved all similar strengths, showing no significant differences between groups. Both conventional Bolomey mixes, with a $0.45 \mathrm{w} / \mathrm{c}$ ratio, used 409 $\mathrm{kg}$ of cement and $184 \mathrm{~kg}$ of water per cubic meter, while the adaptation of the method used $376 \mathrm{~kg}$ and $169 \mathrm{~kg}$, which means a reduction of around $8 \%$ in both cement and water content. Conventional Bolomey mixes, with a $0.6 \mathrm{w} / \mathrm{c}$ ratio, used $307 \mathrm{~kg}$ of cement and $184 \mathrm{~kg}$ of water per cubic meter, while the adaptation used $286 \mathrm{~kg}$ and $171 \mathrm{~kg}$, thus achieving a 7\% reduction in cement and water content.

The compressive strength results for the Bolomey based mixes results are shown in Figure 14. 

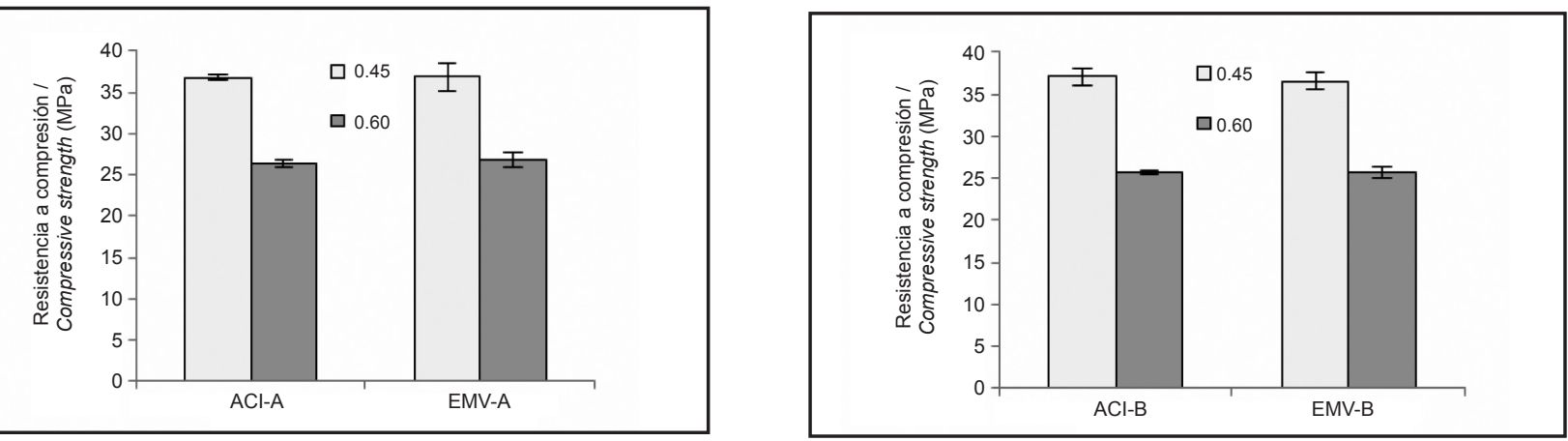

Figura 13. Resistencias a compresión de las mezclas basadas en ACI. Figure 13. ACI based mixes compressive strengths.

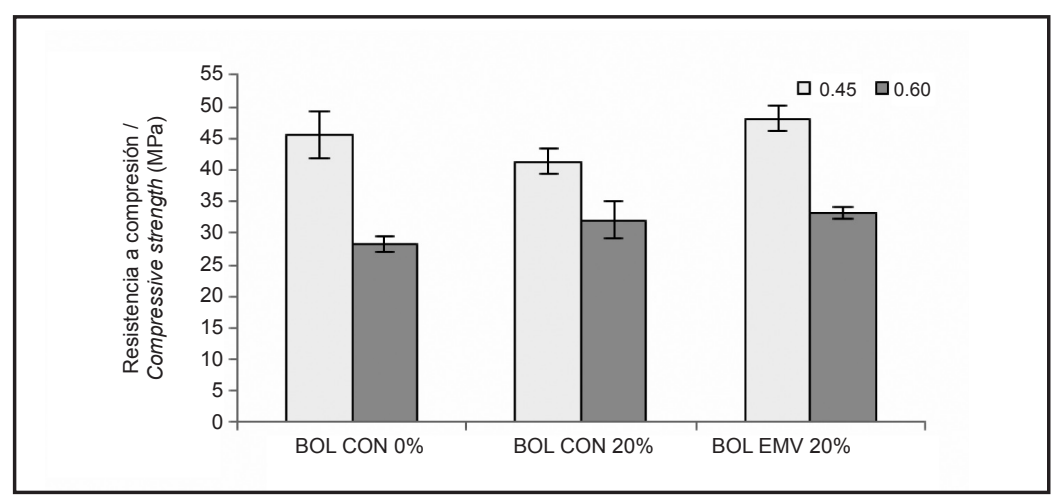

Figura 14. Resistencias a compresión de las mezclas basadas en Bolomey. Figure 14. Bolomey based mixes compressive strengths.

Si bien en este trabajo las mezclas diseñadas con el nuevo método, a excepción de las basadas en Bolomey con relación $a / c$ 0,6, siempre han necesitado una mayor cantidad de aditivo, cabe recordar que en este trabajo no se ha estudiado la eficacia del aditivo con el propósito de mantener la resistencia a compresión, bajando la cantidad de agua y cemento. El aditivo solo se ha utilizado para repetir la experiencia de la investigación original pero utilizando áridos españoles, junto con lograr una trabajabilidad adecuada.

\section{Módulo de elasticidad}

Los módulos de elasticidad han sido obtenidos mediante probetas cilíndricas de 10 × $20 \mathrm{~cm}$, a una edad de 28 días. Los resultados se muestran en las Figuras 15 y 16.

En la primera parte de la investigación, se obtienen mayores resultados de módulo elástico al usar el nuevo método, junto con una reducción de la cantidad de cemento, a excepción de las mezclas EMV-A con relación a/c 0,45.

En el caso de la mezcla EMV-A, comparada con la mezcla ACI-A, con relación a/c 0,6, se obtiene alrededor de un
Even though EMV mixes, with the exception of the Bolomey based ones with $0.6 \mathrm{w} / \mathrm{c}$ ratio, have always needed the use of higher amounts of additive, it is worth to clarify that in this investigation, the efficacy of the additive with the intention of maintaining the compressive strengths, and reducing the water and cement amount, has not been studied. The additive has only been used with the purpose of reproducing the original investigation experience but using Spanish aggregates, and to achieve a desired workability.

\section{Modulus of elasticity}

The elastic modulus has been obtained through $10 \times 20$ cylinder specimens at an age of 28 days. The results are shown in Figures 15 and 16.

Except in the case of the EMV-A mix compared to ACI-A mix, with a $0.45 \mathrm{w} / \mathrm{c}$ ratio, all of the other values show that higher elastic modulus are achieved when using the EMV method compared to the conventional one, in addition to a reduction in the used amount of cement.

In the case of the EMV-A mix with a $0.6 \mathrm{w} / \mathrm{c}$ ratio, around a $23 \%$ increment on the elastic modulus is achieved when 

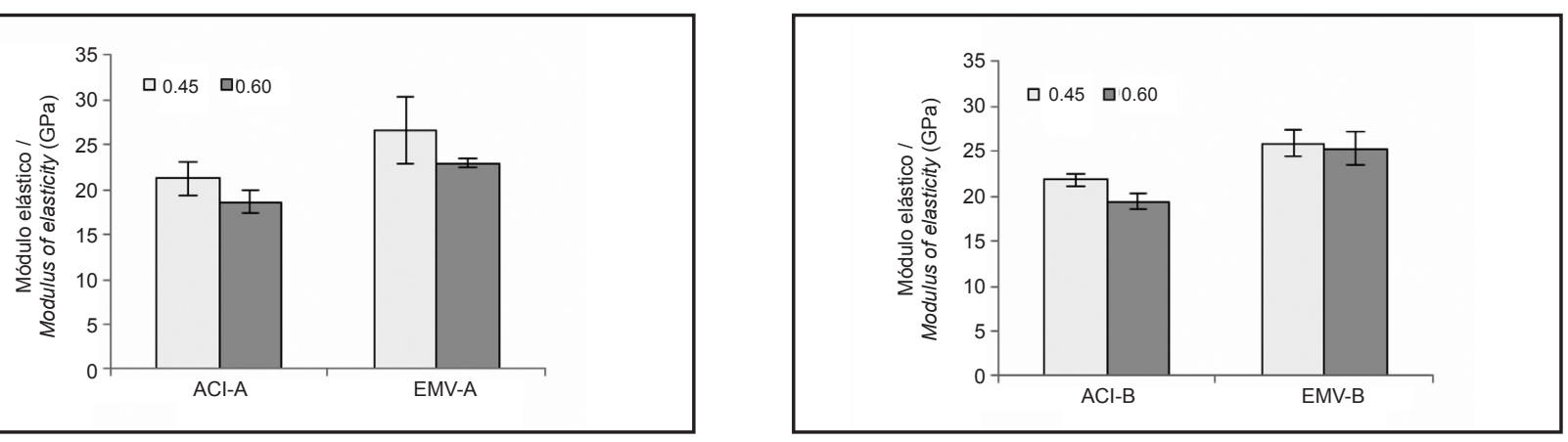

Figura 15. Módulo de elasticidad de muestras basadas en ACI. Figure 15. ACI based mixes modulus of elasticity.

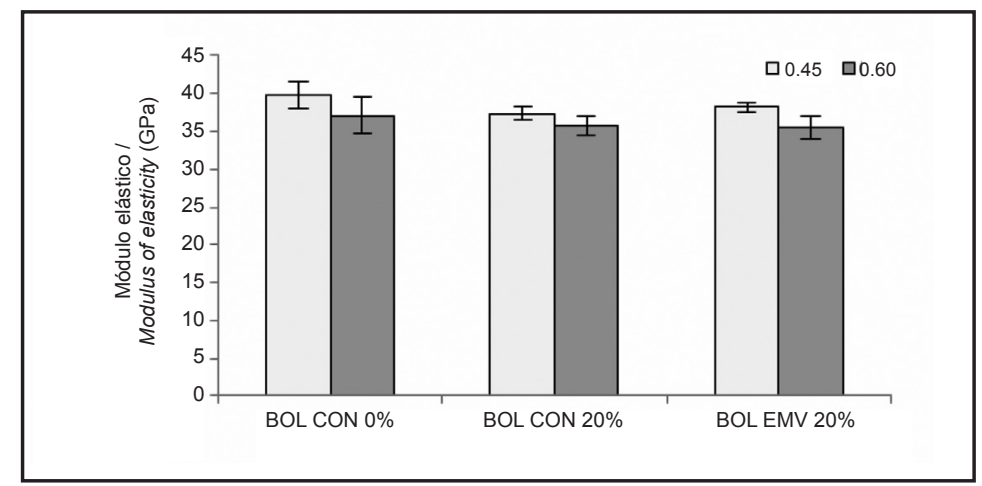

Figura 16. Módulo de elasticidad de muestras basadas en Bolomey. Figure 16. Bolomey based mixes modulus of elasticity.

$23 \%$ de incremento en esta propiedad. La mezcla EMV-B comparada con la ACI-B, con relación a/c 0,45, muestra alrededor de un $19 \%$ de incremento. La mezcla EMV-B comparada con la ACI-B, con relación a/c 0,6, muestra alrededor de un $31 \%$ de incremento.

Estos resultados se justifican en el hecho de que el módulo de elasticidad es una propiedad que está íntimamente ligada con los componentes del hormigón. El mortero tiene un módulo elástico más bajo que los áridos (7), así pues, al reducir la cantidad de éste en la mezcla e incrementar la cantidad de árido grueso, el módulo elástico aumentará. El método EMV logra lo antes mencionado, tras contar la cantidad de mortero adherido de los $\mathrm{ARH}$, para luego restarla del total de mortero necesario por diseño, y luego reemplazarlo por $\mathrm{AN}$, con lo que se obtienen mezclas con similares contenidos de mortero y $\mathrm{AN}$ a las usadas en un HAC.

Se realizó un análisis de varianza entre grupos según el tipo de árido y la relación a/c utilizada, para verificar estadísticamente estos resultados. El análisis mostró que existen diferencias significativas entre un método y el otro, a excepción de las mezclas EMV-A y ACI-A, de relación a/c 0,45 . Esta excepción puede deberse a la ausencia de un comparing it to the ACI-A mix with the same $w / C$ ratio. $E M V-B$ mix with a $0.45 \mathrm{w} / \mathrm{C}$ ratio shows around a $19 \%$ increment on the elastic modulus when compared to the $A C I-B$ mix. EMV-B mix with a $0.6 \mathrm{w} / \mathrm{C}$ ratio shows around a $31 \%$ increment on the elastic modulus when compared to the conventional ACI-B mix.

These results can be justified because of the existent bond between the concrete components and this property. Mortar has a lower elasticity modulus than the aggregates (7), so, by lowering the amount of mortar of the mix and increasing the amount of NA, the elasticity modulus will be higher. The EMV method achieves this by counting the existent mortar, attached to the RCA, within the total amount of mortar needed, thus replacing it with NA, which will end in a concrete mix with mortar and coarse aggregates quantities similar to those used in NAC mixes.

An ANOVA test was carried out between the groups, according to the type of aggregates and the $w / c$ ratios used, in order to statistically verify these results. ANOVA test showed that there are significant differences between the groups when using the EMV method compared to the conventional one, with the exception of the EMV-A and 
resultado de módulo en la mezcla EMV-A, lo que cambiaría el resultado del análisis si suponemos un valor igual al promedio de los otros obtenidos, cambiando la desviación estándar, y, por consiguiente, mostrando una diferencia significativa como resultado del análisis. Esto demuestra que el usar el método EMV, en vez del convencional para HAR, cambiará significativamente los resultados de esta propiedad.

Si bien los resultados de módulos elásticos parecen ser bajos, algunas recomendaciones indican que, al usar reemplazos del $100 \%$ de AR por AN, esta propiedad debería sufrir una reducción de alrededor de un $20 \%$ respecto de un HAC (32), y, más aún, el contenido de aire de la mezcla también podría reducir los valores de esta propiedad (37).

La segunda parte de esta investigación mostró una tendencia diferente de la primera, ya que, tras realizarse el análisis de varianza, no se han encontrado diferencias significativas entre los resultados; sin embargo, los resultados de las mezclas BOL EMV $20 \%$ se han logrado utilizando menor cantidad de cemento. Se logró un ahorro de alrededor de un $8 \%$ del cemento, para las relaciones a/c 0,45 y 0,6 .

También se ha observado que un $20 \%$ de reemplazo en peso de $A R H$, no representa un cambio significativo en los resultados de módulo elástico.

\section{CONCLUSIONES}

Las mezclas basadas en el método de la ACI, diseñadas con el método EMV, utilizando áridos reciclados españoles en su elaboración, logran similares resistencias a compresión, y mayores densidades y módulos elásticos que los HAR diseñados con métodos convencionales.

Las mezclas basadas en el método Bolomey, diseñadas con la adaptación del método EMV, utilizando áridos reciclados españoles en su elaboración, logran similares propiedades a los HAR y HAC diseñados con métodos convencionales.

El árido reciclado $\mathrm{B}$, mostró buenos resultados en las propiedades estudiadas, aún cuando su composición incluyó mayores valores de material bituminoso que los admitidos por la Instrucción Española de Hormigón Estructural.

Los áridos reciclados $\mathrm{A}$ y $\mathrm{B}$, utilizados en la elaboración de las mezclas basadas en la metodología de la ACI, mostraron tendencias similares en las propiedades de resistencia a compresión y módulo de elasticidad.
ACI-A mixes with a $0.45 \mathrm{w} / \mathrm{c}$ ratio. This exception could be explained by the absence of one result on the EMV-A mix, which would change the analysis if we suppose a value equal to the average elasticity modulus obtained, thus changing the standard deviation and therefore showing a significant difference in the statistical analysis. This demonstrates that using the novel method instead of the conventional one, will significantly change the results of this property.

The elastic modulus of these concrete mixes seems to be low, however, some recommendations indicates that there should be a reduction of a $20 \%$ for a recycled concrete made with $100 \%$ replacement of natural aggregates when compared to a conventional one (32) and, moreover, the air content of the mixes may also reduce the values of this property (37).

The second part of the investigation showed a different behaviour compared to the first part, presenting no significant differences between the groups in all of the cases. This was verified with an ANOVA test. Although this, the results of the BOL EMV 20\% mixes were achieved using less amount of cement. There is a reduction of around $8 \%$ in the cement content for both 0.45 and $0.6 \mathrm{w} / \mathrm{c}$ ratios.

It was also observed that a $20 \%$ weight replacement of recycled aggregates does not represent a significant change in the results of this property.

\section{CONCLUSIONS}

ACI based mixes, proportioned by the EMV method, using Spanish RCA, achieve similar compressive strengths, and higher densities and modulus of elasticity than RAC prepared with conventional methods.

Bolomey based mixes, proportioned with the adaptation of the EMV method, using Spanish RCA, achieved similar properties to the NAC and RAC, proportioned by conventional methods.

Recycled aggregate $B$, gave good results in the studied properties, even when its composition included higher amounts of bituminous materials than what the Spanish Instruction for Structural Concrete admits.

Recycled aggregates $A$ and $B$, used in the $A C I$ based mixes, showed similar tendencies in both compressive strength and modulus of elasticity. 
El uso del nuevo método EMV dentro del contexto español es viable, y da excelentes resultados en términos de las propiedades que han sido estudiadas en esta investigación.

La creación de una adaptación del método EMV a la metodología de Bolomey es posible, y, más aun, muestra buenos resultados respecto de las propiedades estudiadas en esta investigación.

Es posible dosificar HAR de igual resistencia al HAC, disminuyendo las cantidades de cemento utilizadas comúnmente. Esto hace que estas nuevas metodologías de diseño sean más amigables con el medio ambiente que las convencionales para HAR.
The use of the EMV method within the Spanish context is viable, and gives excellent results in terms of the studied properties.

The adaptation of the EMV method to Bolomey proportioning methodology is feasible, and, furthermore, it shows good results on the tested concrete properties.

It is possible to design RAC of equal resistances to those of a NAC, by lowering the commonly used amounts of cement. This turns these new design methodologies more environmentally friendly than the conventional ones for RAC.

\section{BIBLIOGRAFÍA / BIBLIOGRAPHY}

(1) Cánovas, M. F.: Hormigón, Colegio de Ingenieros de Caminos, Canales y Puertos, Madrid (2007).

(2) European Topic Centre on Resource and Waste Management: EU as a Recycling Society, European Topic Centre on Sustainable Consumption and Production, Copenhagen (2009).

(3) Agència de Residus de Catalunya. Residus de la construcción, INFORME 2010. Informe Annual, Departament de Territori i Sostenibilitat, Barcelona (2010).

(4) Glavind, A.; Munch-Petersen, C.: "'Green' concrete in Denmark", Structural Concrete, vol. 1, no 1 (2000), pp. 1-7. D.O.I.: 10.1680/ stco.2000.1.1.19.

(5) Razaqpur, A. G.; Fathifazl, G.; Isgor, B.; Abbas, A.; Fournier, B.; Foo, S.: "How to produce high quality concrete mixes with recycled concrete aggregate", Construction Waste Recycling and Civil Engineering Sustainable Development, Proceedings of the ICWEM 2010 (2010), pp. 11-35.

(6) ACI Committe 555: Removal and Reuse of Hardened Concrete - ACI 555R-01, ACI Committee, Detroit (2001).

(7) Hansen, T. C.: Recycling of Demolished Concrete and Masonry. RILEM, Londres (1992).

(8) EPA - U.S. Environmental Protection Agency: Inventory of U.S. Greenhouse Gas Emissions and Sinks (EPA 430-R-11-005), EPA (U.S. Environmental Protection Agency), Washington (2011).

(9) Maier, P. L.; Durham, S. A.: "Beneficial use of recycled materials in concrete mixtures", Constr. and Build. Mater., no 29 (2012), pp. 428-437. D.O.I.: 10.1016/j.conbuildmat.2011.10.024.

(10) Comité Técnico AEN/CTN 80 Cementos y Cales: Cemento. Parte1: Composición, especificaciones y criterios de conformidad de los cementos comunes, AENOR, Madrid (2000).

(11) Comité Técnico AEN/CTN 146 Áridos: UNE-EN 933-11:2009. Ensayos para determinar las propiedades geométricas de los áridos. Parte 11: Ensayo de clasificación de los componentes de los áridos gruesos reciclados, AENOR, Madrid (2009).

(12) Comisión Permanente del Hormigón: Instrucción de Hormigón Estructural. EHE-08, Ministerio de Fomento, Madrid (2008).

(13) Tam, V. W. Y., Gao, X. F., Tam, C. M., Chan, C. H.: "New approach in measuring water absorption of recycled aggregates", Constr. and Build. Mater. , no 22 (2008), pp. 364-369. D.O.I.: 10.1016/j.conbuildmat.2006.08.009.

(14) Neville, A. M.; Brooks, J. J.: Concrete Technology, Prentice Hall, Harlow (2010).

(15) Gómez-Soberón, J. M. V.; Vázquez Ramonich, E.; Agulló Fité, L.: Hormigón con Áridos Reciclados. Una Guía de Diseño para el Material, Barcelona (2001).

(16) López-Gayarre, F.; Serna, P.; Domingo-Cabo, A.; Serrano-López, M. A.; López-Colina, C.: "Influence of recycled aggregate quality and proportioning criteria on recycled concrete properties". Waste Management, no 29 (2009), pp. 3022-3028. D.O.I.: 10.1016/j. wasman.2009.07.010.

(17) Corinaldesi, V.: "Mechanical and elastic behaviour of concretes made of recycled-concrete coarse aggregates", Constr. and Build. Mater., no 24 (2010), pp. 1616-1620. D.O.I.: 10.1016/j.conbuildmat.2010.02.031.

(18) Gómez-Soberón, J. M. V.: "Porosity of recycled concrete with substitution of recycled concrete aggregate. An experimental study", : Cem. Concr. Res., no 32 (2002), pp. 1301-1311. D.O.I.: 10.1016/S0008-8846(02)00795-0.

(19) Abbas, A.; Fathifazl, G.; Isgor, O. B.; Razaqpur, A. G.; Fournier, B.; Foo, S.: "Durability of recycled aggregate concrete designed with equivalent mortar volume method", Cem. Concr. Comp., no 31 (2009), pp. 555-563. D.O.I.: 10.1016/j.cemconcomp.2009.02.012. 
(20) Comité Técnico AEN/CTN 146 Áridos: UNE-EN 1097-6:2000. Ensayos para determinar las propiedades mecánicas y físicas de los áridos. Parte 6: Determinación de la densidad de partículas y la absorción de agua, AENOR, Madrid (2000).

(21) ASTM International: ASTM C 29/C 29M -09. Standard Test Method for Bulk Density (Unit Weight) and Voids in Aggregate, ASTM International, West Conshohocken (2009).

(22) Abbas, A.; Fathifazl, G.; Fournier, B.; Isgor, O. B.; Zavadil, R.; Razaqpur, A. G.: "Quantification of the residual mortar content in recycled concrete aggregates by image analysis", Materials Characterization, no 60 (2009), pp. 716-728. D.O.I.: 10.1016/j.matchar.2009.01.010.

(23) Barra, M.: Estudio de la durabilidad del hormigón de árido reciclado en su aplicación como hormigón armado, Barcelona (1996).

(24) Morlion, D.; Venstermans, J.; Vyncke, J.: Demolition of the Zandvliet lock as aggregates for concrete. In RILEM. Demolition and reuse of concrete and masonry, Chapman and Hall Ltd, Londres (1988).

(25) ACI Committee 211: Standard Practice for Selecting Proportions for Normal, Heavyweight, and Mass Concrete (ACI 211.1-91), American Concrete Institute, Detroit (2002).

(26) Fathifazl, G.; Abbas, A.; Razaqpur, A. G.; Isgor, O. B.; Fournier, B.; Foo, S.: "New Mixture Proportioning Method for Concrete Made with Coarse Recycled Concrete Aggregate", Journal of Materials in Civil Engineering (2009), pp. 601-611. D.0.I.: 10.1061/(ASCE)08991561(2009)21:10(601).

(27) ASTM International: ASTM C143/C 143M - 10a Standard Test Method for Slump of Hydraulic Cement Concrete, ASTM International, West Conshohocken (2010).

(28) ASTM International: ASTM C231/C 231M - 10 Standard Test Method for Air Content of Freshly Mixed Concrete by the Pressure Method, ASTM International, West Conshohocken (2010).

(29) ASTM International, ASTM C 642 - 06. Standard Test Method for Density, Absorption, and Voids in Hardened Concrete, ASTM International, West Conshohocken (2006).

(30) Comité Técnico AEN/CTN 83 Hormigón: UNE-EN 12390-3:2009/AC. Ensayos de hormigón endurecido. Parte 3: Determinación de la resistencia a compresión de probetas, AENOR, Madrid (2009).

(31) Comité Técnico AEN/CTN 83 Hormigón: UNE 83316:1996. Ensayos de hormigón. Determinación del módulo de elasticidad en compresión. AENOR, Madrid (1996).

(32) Sánchez de Juan, M.: Estudio sobre la utilización de árido reciclado para la fabricación de Hormigón Estructural, Madrid (2004)

(33) Cement \& Concrete Institute: Admixtures for Concrete, Cement \& Concrete Institute, Midrand (2009).

(34) ACI Committee E-701: Chemical Admixtures for Concrete, American Concrete Institute, Detroit (2003).

(35) Cement Admixtures Association: Admixture Sheet - ATS 5. Concrete Air-entraining admixtures, Cement Admixtures Association, Knowle (2006).

(36) ESStech: C - 11: Air-Entrainment: Benefits \& Pitfalls. Italcementi Group.

(37) National Cooperative Highway Research Program: NCHRP Report 578. Evaluating Air-Entraining Admixtures for Highway Concrete, American Association of State Highway and Transportation Officials, Washington, D.C. (2007).

(38) National Ready Mixed Association: CIP 15 - Chemical Admixtures for Concrete, National Ready Mixed Association, Silver Spring (2001).

(39) Portland Cement Association: Concrete Technology, PCA Portland Cement Association, Online, visitado: 16/02/2012. http://www. cement.org/tech/cct_admixtures_AEA.asp 